Florida International University FIU Digital Commons

$1-16-1986$

\title{
Investigation into possible causes of elevated ozone concentrations in Miami, Florida
}

Dale E. Aspy

Florida International University

DOI: $10.25148 /$ etd.FI14032361

Follow this and additional works at: https://digitalcommons.fiu.edu/etd

Part of the Other Environmental Sciences Commons

\section{Recommended Citation}

Aspy, Dale E., "Investigation into possible causes of elevated ozone concentrations in Miami, Florida" (1986). FIU Electronic Theses and Dissertations. 1329.

https://digitalcommons.fiu.edu/etd/1329

This work is brought to you for free and open access by the University Graduate School at FIU Digital Commons. It has been accepted for inclusion in FIU Electronic Theses and Dissertations by an authorized administrator of FIU Digital Commons. For more information, please contact dcc@fiu.edu. 


\section{ABSTRACT}

INVESTIGATION INTO THE POSSIBLE CAUSES OF

ELEVATED OZONE CONCENTRATIONS IN

MIAMI, FLORIDA

By

Dale E. Aspy

Ozone readings which exceeded the National Ambient Air Quality Standard of 120 ppbv were recorded in Miami, Florida during 1978 and 1980. Similar elevated concentrations of ozone extended across upper Florida and into the Southeastern portion of the United states. It is concluded that tropospheric transport of ozone into the Miami area occurs. This conclusion is supported by lead analyses of atmospheric samples taken in Miami and by isentropic trajectories. Six case studies are presented. In all cases transport of ozone into Florida appears to occur. In only four of the cases does this result in elevated ozone levels in Miami. In one case lower Florida was experiencing an oceanic influx of air and low ozone concentrations. In the other case Miami was experiencing a stagnation and high ozone concentrations apparently generated locally. The long range transport of ozone across the Southeastern United States appears to result from circulation within a weather pattern characterized by a stagnant high pressure system over the Southeastern United States. 


\section{INVESTIGATION INTO POSSIRLE CAUSES OF \\ ELEVATED OZONE CONCENTRATIONS IN \\ MIAMI , FLORIDA}

by

Dale E. Aspy

A thesis in partial fulfillment of the requirement for the degree of

MASTER OF SCIENCE

in

FNVIRONMENTAL AND URBAN SYSTEMS

FLORIDA INTERNATIONAL UNIVERSITY

December 1985 


\title{
INVESTIGATION INTO POSSIRLE CAUSFS OF FLEVATFD O7,ONF CONCFNTRATIONS IN \\ MIAMI, FLORIDA
}

\author{
by
}

$$
\text { Dale E. Aspy }
$$

\section{A thesis submitted in partial fulfillment of the requirements for the degree of}

\author{
MASTEP OF SCIENCE \\ in \\ ENV JRONMFNTAL AND URBAN SYSTEMS \\ at \\ FLORIDA JNTERNATIONAL INIVERSITY
}

Committe in charge:

Dr. Howard E. Moore

Professor and Committee

Chairperson

Dr. Jose T Villate

Professor

Dr. John H. Parker

Associate Professor

December, 1985 
To: Dr Howard E. Moore, Dr Jose T. Villate and Dr. John H. Parker

This thesis, having been approved in respect to form and mechanical execution, is referred to you for judgement upon its substantial merit.

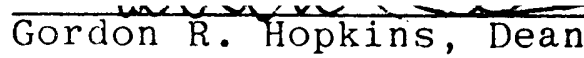

College of Engineering

The thesis of Dale E. Aspy is approved.
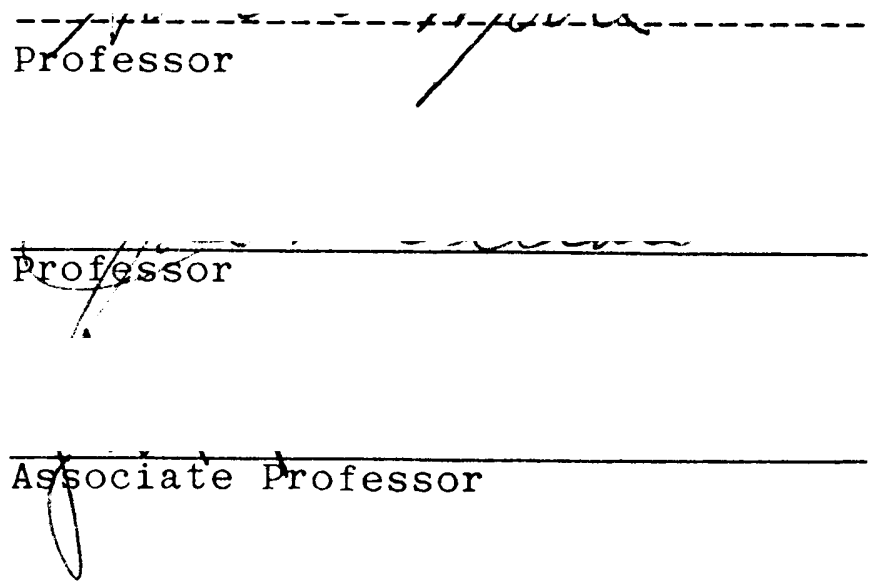

Date of Examination:

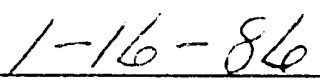




\section{ACKNOWLEDGEMENTS}

The author wishes to acknowledge Dr. Howard Moore for his support and valuable assistance. The author extends special thanks to Dr. Phillip Haagenson of the National Center for Atmospheric Research in Boulder, Colorado for calculating the reverse isentropic trajectories that are a vital part of this thesis. 
List of Tables $\ldots \ldots \ldots \ldots \ldots \ldots \ldots \ldots \ldots \ldots \ldots \ldots \ldots \ldots \ldots \ldots$

List of Figures $\ldots \ldots \ldots \ldots \ldots \ldots \ldots \ldots \ldots \ldots \ldots \ldots \ldots \ldots$

I. INTRODUCTION $\ldots \ldots \ldots \ldots \ldots \ldots \ldots \ldots \ldots \ldots \ldots \ldots \ldots \ldots \ldots \ldots$

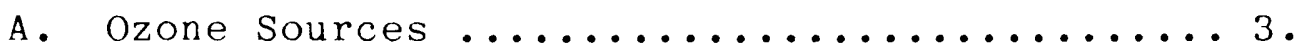

B. Aesthetic and Health Effects of Ozone ......6.

C. Ozone Regulations and Standards .......... 10 .

D. Possible Sources of Ozone in Miami ....... 12 .

I . EXPERIMENTAL PROCEDURES $\ldots \ldots \ldots \ldots \ldots \ldots \ldots \ldots$

A. Ozone Analysis ....................

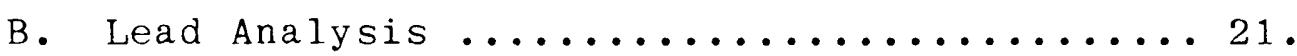

C. Strontium-90 Analysis ................

D. Air Trajectory Analysis ............. 26 .

III. PRESENTATION AND DISCUSSION OF DATA $\ldots \ldots \ldots \ldots 27$.

A. August $18-24,1980$ Episode $\ldots \ldots \ldots \ldots \ldots \ldots 28$.

B. October 16-18, 1980 Episode ........... 45 .

C. August 7-10, 1980 Episode ............ 53 .

D. June $7-10,1980$ Episode ............. 54 .

E. October 5-7, 1978 Episode ............ 59 .

F. July 13-16, 1980 Episode ............6. 63 .

IV CONCLUSIONS $\ldots \ldots \ldots \ldots \ldots \ldots \ldots \ldots \ldots \ldots \ldots \ldots \ldots \ldots \ldots$

v. REFERENCES $\ldots \ldots \ldots \ldots \ldots \ldots \ldots \ldots \ldots \ldots \ldots \ldots \ldots \ldots \ldots \ldots \ldots \ldots$ 


\section{LIST OF TABLES}

Page

I . ACCEPTANCE TEST RESULTS ON S\&S-1HV FILTERS $\ldots . .23$. I I SUMMARY OF OZONE EPISOdE PATTERNS $\ldots \ldots \ldots \ldots \ldots 73$. 
1. SAMPLING Sites In DAdE COUNTY $\ldots \ldots \ldots \ldots \ldots \ldots \ldots \ldots$.

2. DAILY OZONE AND LEAD CONCENTRATIONS: DADE COUNTY,

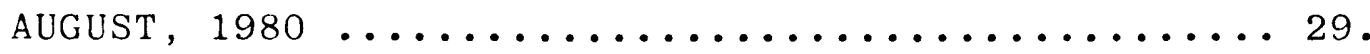

3. OZONE CONCENTRATIONS: SOUTHEAST FLORIDA,

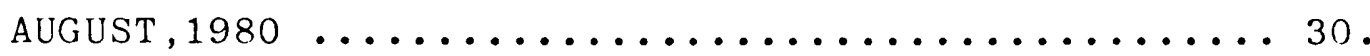

4. OZONE CONCENTRATIONS: tampa BAT AREA, AUgust, 1980 - 32 . 5. OZONE CONCENTRATIONS: UPPER FLORIDA, AUGUST, 1980 . 33. 6. OzOne Concentrations: Alabama, August, $1980 \ldots \ldots . .34$.

7. OZONE CONCENTRATiOnS: GEORgIA, AUGUSt, 1980 ..... 35 .

8. OZONE CONCENTRATIONS: GEORGIA, AUGUSt, $1980 \ldots \ldots . .36$.

9. OZONE CONCENTRATIONS: SOUTH CAROLINA, AUGUST, 198037.

10. OZONE CONCENTRATions: SOUTh CAROLINA, AUgust, 198038.

11. Weather pattern: August 19, $1980 \ldots \ldots \ldots \ldots \ldots \ldots$..... 40 .

12. Weather pattern: August $20,1980 \ldots \ldots \ldots \ldots \ldots \ldots . \ldots 4$.

13. Weather pattern: august $21,1980 \ldots \ldots \ldots \ldots \ldots \ldots$. 42 .

14. Weather pattern: August $22,1980 \ldots \ldots \ldots \ldots \ldots \ldots \ldots$.

15. ISENTROPIC TRAJECTORIES: AUGUST 18-24, 1980

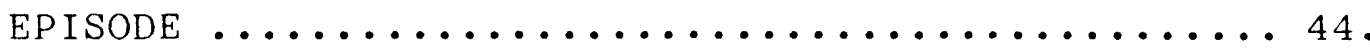

16. DAILY OZONE AND leAd CONCENTRATiOnS: DADE COUNTY,

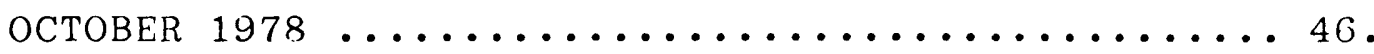

17. OZOne CONCENTRATions: DAdE COUnty, octoBer, 1978 . 47. 18. OZONE CONCENTRATIONS: TAMPA BAY AREA, OCTOBER, $1978 \ldots \ldots \ldots \ldots \ldots \ldots \ldots \ldots \ldots \ldots \ldots \ldots \ldots$. 
19. OZONE CONCENTRATIONS: UPPER FLORIDA,

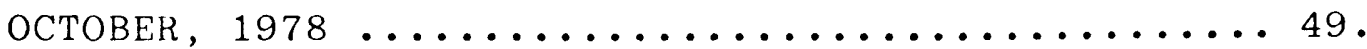

20. OZONE CONCENTRATIONS: GEORGIA, OCTOBER, $1978 \ldots \ldots .50$.

21. Weather pattern: october $16,1978 \ldots \ldots \ldots \ldots \ldots \ldots \ldots$.

22. ISENTROPIC TRAJECTORIES: OCTOBER 16-18, 1978

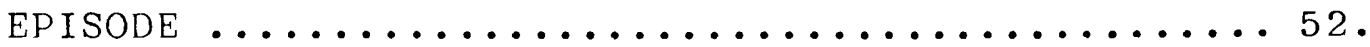

23. ISENTROPIC TRAJECTORIES: AUGUST 7-10, 1980 EPISODE 55.

24. DAILY OZONE AND LEAD CONCENTRATiOnS: DADE COUNTy,

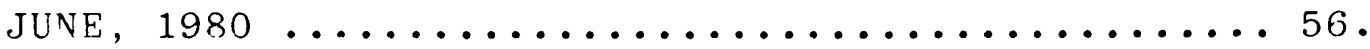

25. OZONE CONCEnTRATiOns: DADE COUNTy, June, $1980 \ldots \ldots 57$. 26. OZONE CONCENTRATIONS: TAMPA BAY AREA, JUNE, 1980 . 58 . 27. OZONE CONCENTRATIONS: UPPER FLORIDA, JUNE $1980 \ldots 60$. 28. ISENTROPIC TRAJECTORIES: JUNE 7-10, 1980 EPISODF .. 61. 29. ISENTROPIC TRAJECTORIES: OCTOBER 5-7, 1978 EPISODE 62. 30. DAILY OZONE AND LEAD CONCENTRATiONS: DADE COUNTy,

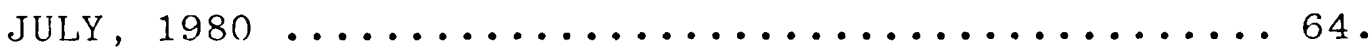

31. OZONE CONCENTRATIONS: SOUTHEAST FLORIDA,

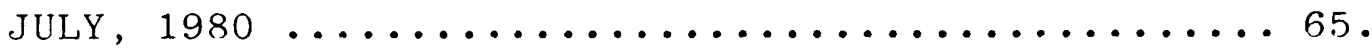
32. OZONE CONCENTRATIONS: TAMPA BAY AREA, JULY, $1980 \ldots 66$. 33. OZONE CONCENTRATIONS: UPPER FLORIDA, JULY, 1980 .. 67. 


\section{INTRODUCTION}

Ozone levels in Dade County, Florida, during the months of October, 1978 and August, 1980 were found to exceed the National Ambient Air Quality Standard of 120 parts per billion (ppbv). The State and Local Air Monitering System for Dade County is shown in Figure 1. Ozone concentrations at both the rural, inland Thompson Park site, station number 35, and the coastal Virginia Key location, station number 36, were elevated. These sites were selected by representatives from the Dade County Department of Environmental Resources Management, the Florida Department of Environmental Regulation-Bureau of Air Quality Management, and the United States Environmental Protection Agency-Region IV. The two monitoring locations were selected so as to sample both upwind and downwind of Miami's urban core during spring, summer and early fall. These time periods represent the peak oxidant season for this latitude.

Preliminary modeling by the Environmental protection Agency indicated that the peak standard might be exceeded at Thompson Park, in accordance with classical concepts of ozone production. This theory of ozone generation states that hydrocarbon compounds and nitrogen dioxides emitted from vehicular sources are the primary causes of ozone. These ozone precursors, as they are known, react in the presence of sunlight to form ozone. Classical ozone modeling theory indicated that the predominant southeasterly breeze would carry only pristine maritime air over the 


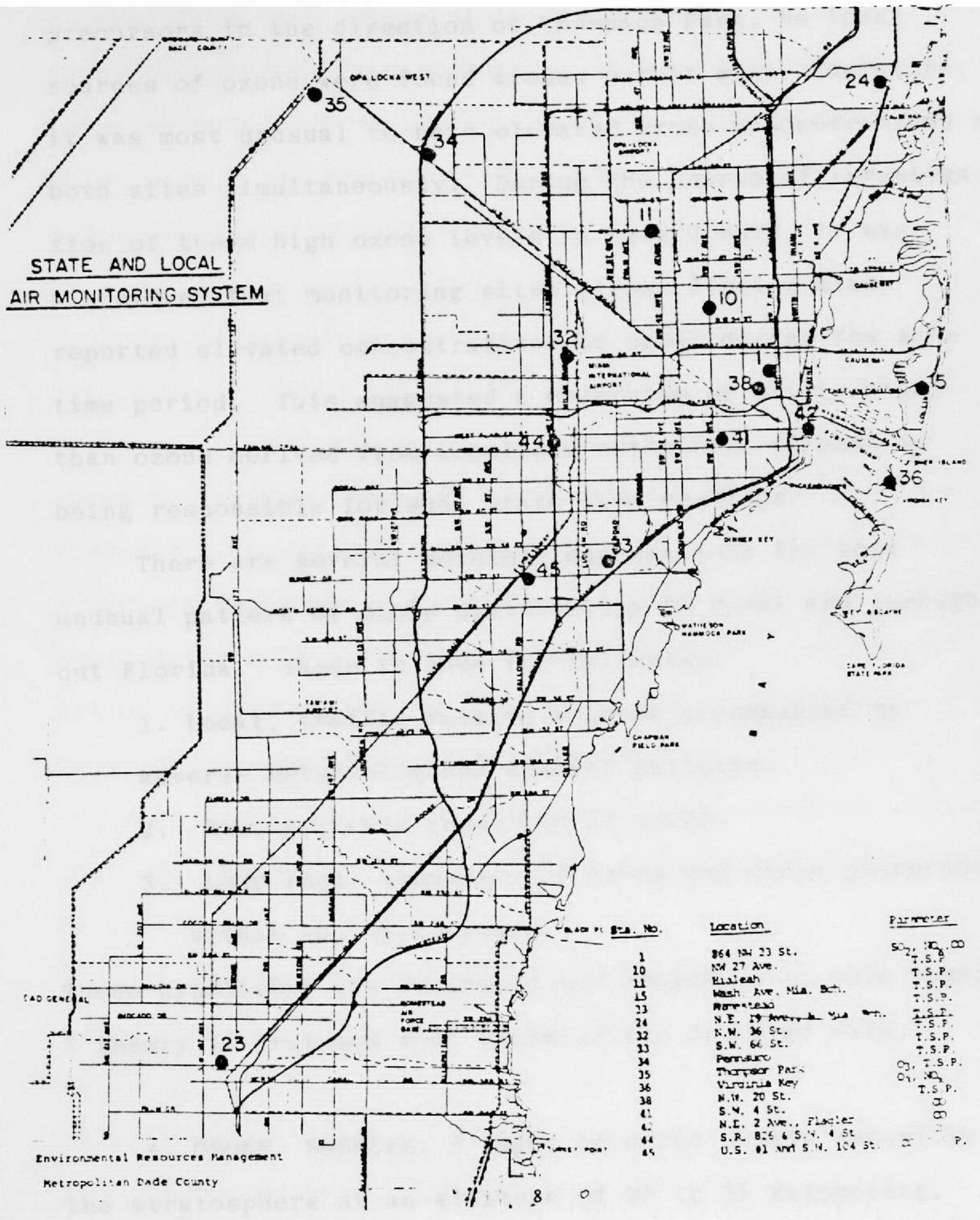

FIGURE 1: SAMPLING SITES IN DADE COUNTY 
Virginia Key site while the same breeze would carry ozone precursors in the direction of Thompson Park. No local sources of ozone were found around either site. Therefore, it was most unusual to have elevated ozone concentrations at both sites simultaneously. During the course of investigation of these high ozone levels in Dade County, it was discovered that monitoring sites across Florida also reported elevated concentrations of ozone during the same time period. This suggested a mechanism or source other than ozone derived from localized automobile exhaust as being responsible for such state wide readings.

There are several possible explanations for this unusual pattern of ozone distribution in Miami and throughout Florida. These include the following:

1. Local, traffic related sources accompanied by adverse meteorological weather patterns.

2. Stratospheric injection of ozone.

3. Long range transport of ozone and ozone precursors within the troposphere.

These hypotheses are discussed and evaluated in this thesis. A theory is proposed that explains the observed data.

A. OZONE SOURCES. A layer of ozone exists naturally in the stratosphere at an altitude of 20 to 25 kilometers, depending on latitude and season. Junge (1963) reported a marked concentration increase of ozone with altitude between 13 and 27 kilometers. The concentration of ozone then 
decreases at a regular rate with altitude above $30 \mathrm{kilo-}$ meters. Junge noted this rate of decrease is slightly faster than the decrease in air density. This strato-spheric ozone layer is formed primarily by the photodissociation of molecular oxygen. Williamson (1973) lists the following equations for the stratospheric formation of ozone,

$$
\begin{aligned}
& \mathrm{O}_{2}+\mathrm{h \nu}---\mathrm{O}^{\bullet}+\mathrm{O}^{\bullet} \\
& \mathrm{O}^{\cdot}+\mathrm{O}_{2}+\mathrm{M}--\rightarrow \mathrm{O}_{3}+\mathrm{M}
\end{aligned}
$$

where $h$ is the energy of the absorbed ultraviolet radiation and $M$ is any other molecule, usually $\mathrm{O}_{2}$ or $\mathrm{N}_{2}$, that interacts momentarily with the colliding $\mathrm{O}^{*}$ and $\mathrm{O}_{2}$ to absorb some of the excess energy and momentum. This reaction is driven by ultraviolet 1 ight shorter than 0.24 microns in wave length. The maximum average ozone concentration reported by williamson is 200 ppbv and was observed at an altitude of 26 kilometers at the equator and 18 kilometers at the Earth's poles.

It was previously thought that the transport rate for ozone from the stratosphere into the troposphere was quite slow. Danielson (1968) proved that stratospheric ozone can be injected into the troposphere by mechanisms such as atmospheric folding. Tropospheric air enters the stratosphere when large values of potential temperature occur at low latitudes. As air enters the stratosphere it gains radioactivity, potential vorticity and ozone. High latitude 
radiative cooling transports the air mass to lower potential temperature levels in the stratosphere. It is then transported towards the equator by baroclinic waves and is folded into the atmosphere by amplifying vortices. Other investigators (Wolff et al., 1977; Haagenson, 1981; Husian et al., 1977) have confirmed these observations.

The Environmental Protection Agency list of priority air pollutants that are required to be monitored by state and local air pollution agencies consists of the following: nitrogen dioxide. sulfur dioxide, carbon monoxide, total suspended particulates and ozone. Ozone is unique in that it is a secondary, rather than primary, air pollutant. The term secondary air pollutant means that the pollutant itself is not usually directly emitted by any source. Rather ozone is formed by the reaction of various organic free radicals with oxides of nitrogen that are released by air pollution sources. Laboratory smog chamber studies show the reaction sequence consists of about 30 steps. The main reactions (EPA, 1978) consist of:

$$
\begin{aligned}
& \mathrm{NO}_{2}+\mathrm{h \nu}-\cdots \rightarrow \mathrm{NO}+\mathrm{O}^{\circ} \\
& \mathrm{O}_{2}+\mathrm{O}^{\cdot}-\cdots-\mathrm{O}_{3} \\
& \mathrm{O}_{3}+\mathrm{NO}--->\mathrm{NO}_{2} \mathrm{O}_{2} \\
& \mathrm{ROO}{ }^{\circ}+\mathrm{NO}+-->\mathrm{NO}_{2}+\mathrm{RO}{ }^{\circ}
\end{aligned}
$$

In these reactions the $\mathrm{NO}_{2}$ is preserved and may cycle 
through the reactions several times producing more $\mathrm{O}_{3}$. The $\mathrm{ROO}^{*}$ and $\mathrm{RO}^{*}$ represent organic free radicals.

The Environmental Protection Agency (1978) lists the sources of the required compounds as primarily combustion sources especially automobiles. Another major source for these ozone precursors are large hydrocarbon sources such as refineries. Minor sources of ozone are listed as electrostatic precipitators, high voltage power lines and ozonators for drinking water treatment. The Environmental Protection Agency believes that most of the ozone in the troposphere is anthropogenic in origin.

There are naturally occurring sources of ozone in the troposphere (EPA, 1978), such as the reaction of oxides of nitrogen with turpenes that are emitted from coniferous trees. The resultant haze gives the Smokey Mountains their name. Another source of naturally occurring ozone is forest fires.

As can be seen in Equation 3 above, energy is necessary for the formation of ozone. The form of energy is usually ultraviolet sunlight. For this reason high altitude areas with plentiful sunlight and a large number of sources of ozone precursors, such as automobiles, are especially susceptible to high concentrations of ozone.

B. AESTHETIC AND HEALTH EFFECTS OF OZONE. Ozone is of major concern as an air pollutant. This triatomic form of oxygen is the second strongest oxidizing agent known, behind 
only elemental flourine. This tremendous oxidizing powr.r causes deterioration in both organic and inorganic matter. One of the first noted symptoms of ozone-caused deterioration in non-living material was the formation of cracks in rubber products such as automobile tires. This was first diagnosed by Van Rossen et al. (1931) as being caused by ozone and not solely sunlight. Especially sensitive to ozone attack are elastomer-containing materials, textiles, dyes and paints. Other substances, such as building materials and steel, have reduced sensitivity to ozone. The Environmental Protection Agency (1.978) estimated a cost of 37 to 61 million dollars annually nationwide due to increased elastomer damage alone resulting from an increase in the average ozone concentration from $50 \mathrm{ppbv}$ to $70 \mathrm{ppbv}$.

Ozone was first observed to damage plant life in the Southern Calfornia area (Adams, 1956). Now damage to plants is observed in most major metropolitan areas in the United States (EPA, 1978). Primary ozone damage is to the stomata in plant leaves. Tingey (1977) showed that for damage to occur ozone must pass through the stomata and then dissolve in the aqueous cell wall coating. Mansfield (1973) reported that the stoamta are attacked first and are rendered incapable of closure. This prevents them from protecting the internal structure of the leaf. Young plants are especially susceptible. The stanford Research Institute in a report for the Environmental Protection Agency (Benedict et a 1., 1971) estimated the cost to producers to be 125 
million dollars for ozone damage to commercial crops and ornamental plants in the United States. The cost to consumers would be almost double. This estimate was based primarily on visible symptoms of damage. The report also concluded the loss would be almost 300 million dollars in 1974 if ozone levels continued to increase nationwide. Contrary to medical claims made during the first half of this century, ozone has been found to have far reaching harmful effects on the human body. Ozone is sometimes described as radiometric, mimicking ionizing radiation, in its attack on body tissues and systems.

While ozone has not been found to cause cancer in a manner similar to radiation, both cause the release of free radicals. Bhatnagar (1977) found the main toxic component of both ozone and oxygen to be the superoxide free radical, $\mathrm{O}_{2}$. Mustafa et al. (1977) showed that the presence of this free radical stimulates the production of a protective enzyme, superoxide dismutase. They also found other biological effects of ozone within the cell. Monamine oxidase, which acts as a catalyst for the oxidative deamination of amines and as such is of major importance in the regulation of the metabolic degradation process, was found to be hindered by ozone (Hathaway and Terril, 1962). They also reported that sulfhydryl groups were found to be oxidized either directly by ozone or by released free radicals. This suggests that ozone interferes with cellular metabolism. Walbott (1973) reported that ozone interferes wjth the 
normal operation of enzyme systems, such as alkaline phosphatase.

Some of the first occurring effects in humans after exposure to 200 to 400 ppbv of ozone are: bronchiolar region lesions, alterations in the alveolar basement membrane, engorged capillaries adjacent to the alveoli, and a shift in cell types (Mudd and Freeman, 1977). Beull et al. (1965) found a decrease in lung elasticity believed to result from aldehyde compounds promoting cross linkages to form in pulmonary cells. Easton and Murphy (1967) found a decreased airway caliber with attendant flow restriction caused by bronchioconstriction. This results from histamine that is released from damaged mast cells.

Stern (1977) has reported seven nonpulmonary effects of ozone. These are (1) spherring of erythrocytes (red blood cells), (2) chromosome breakage in lymphocytes, (3) alterations in the cell membrane and nuclei of myocardial cells, (4) decreased brain serotonin levels, (5) increased RNA to DNA ratios in the liver, (6) premature aging of the body, and (7) morphological changes in parathyroid gland. stern also reported that ozone acts as a depressiant on the nervre endings in the section of the brain that controls respiration. Ishida and Takashi (1975) found ozone can cause damage to DNA.

Gross manifestation of ozone-induced damage include eye irritation and respiratory distress. Many epidemiological studies of human response have been conducted. Hospital 
admissions during ozone episodes result in mixed results, according to the Fnvironmental Protection Agency (1978). They state that since many factors, such as other air pollutants, ambient temperature, and other atmospheric conditions are involved it is difficult to reach any agreement.

Better agreement is reached by epidemiological studies of asthma and emphysema attacks during ozone episodes. This increase in correlation is presumably due to a much smaller time interval between high ozones periods and the manifestations of the first symptoms in sensitive individuals. These studies include those of Schoetilin and Landau (1961) on asthma patients and Motley et al. (1959) and Remmers and Balchum (1965) with emphysema patients. In these studies the number of reported incidents in the target populations increased with the frequency and severity of ozone episodes.

\section{OZONE REGULATIONS AND STANDARDS. The Environmental} Protection Agency is charged with the responsibility of studying ozone and establishing standards that protect both the public health and aesthetic values by the clean Air Act of 1970. A National Ambient Quality Standard for ozone has been established to achieve that goal. The standard allows a maximum one hour average ozone concentration of $120 \mathrm{ppbv}$ occurring in a predefined geographical area on an average of less than or equal to once per year (EPA, 1979a). More specifically, a given area is said to be in attainment of the ozone standard only if three or fewer one hour average 
ozone concentrations above 120 ppbv are measured any time during three consecutive years. This means that if three readings of $130 \mathrm{ppbv}$ are measued in one year and all other readings are below 120 ppbv for the next two years the area is declared as meeting the standard. However, if two years have a maximum one hour average of 130 ppbv each and the third year has two hours at the same concentration the area is declared "non-attainment" and subject to federal sanctions. This is true even if all other readings during the three year period are zero. Prior to 1979 the National Ambient Air Quality Standard for ozone was 80 ppbv for a one hour average measured once per year. The state of Florida adopted the new Federal standard of 120 pubv in 1982 .

The Environmental Protection Agency can impose sanctions against a defined geographical area, technically called an Air Quality Control Region, if the Air Quality Standard is violated. This non-attainment status can include a mandatory inspection and maintenance program for all vehicles, revised traffic control measures such as traffic light sychronization and maximizing vehicular flow, operating restrictions for stationary air pollution sources such as power plants and factories, and possible denial of operating permits for new sources of air pollution. If the local government does not take steps to reduce ozone levels in a non-attainment area the Environmental Protection Agency can force the Federal Government to withhold all grants and monies to the area. This philosophy is based on the premise 
that ozone, being so highly reactive, is confined to areas of local generation and not subject to long range transport like other air pollutants. Thus the Environmental Protection Agency presumes that local sources and control applications are responsible for local ozone concentrations. Data presented below indicates this assumption may not be entirely correct.

D. POSSIBLE SOURCES OF OZONE IN MIAMI. The possible sources that may account for elevated ozone concentrations in Miami were mentioned above. The first possibility, local sources, will be recognized as the classical concept of the ozone production model. This model was first proposed by Haagen-Smite (1952) following smog chamber tests in attempts to duplicate observed conditions in IJos Angeles smog.

The principle chemical reactions in ozone production have been presented in equations 3 through 6 . The South Florida ozone precursor source consists mainly of automobiles. A possibile complicating factor would be the presence of unique coastal meterological conditions in South Florida. More specifically, the operation of a sea-breeze mechanism may exacerbate the ozone concentrations. The combined ozone production/sea-breeze effect mechanism would work in the following manner: ozone precursors from the morning rush hour traffic are drawn from land to ocean by the differential cooling of land versus sea. The precursors of ozone are contained in this now maritime air mass. They 
react in the presence of sunlight and, as the land becomes warmer than the ocean, are blown back to shore in the afternoon sea breeze. This mechanism has been documented by the Texas Air Control Board (1974) for barrier islands around Galvanston Bay. Since this is only a coastal effect, the inland areas of Florida should not have experienced ozone levels during the same time periods as South Florida. Clearly the ozone production phenomenon was not limited in geographic scope to South Florida. This is discussed more fully below.

Much research has been conducted on the second possibile explanation, that of stratospheric injection of ozone into the troposphere. Junge (1963) reported, based on then available data, an ozone residence time in the stratosphere of one or two years with very little, if any, movement between the troposphere and the stratosphere. Subsequent research by several individuals including Haagenson et al. (1981), Husian et al. (1977), and Wolff et al. (1977) have shown that ozone from the stratosphere can be injected into the troposphere. This has been found to occur on the "back" side of high pressure systems. Evidence of stratospheric air in the troposphere comes not only from elevated ozone levels but also from the presence of various radioisotopes, such as beryllium-7, in greater concentrations than usual in the troposphere. This phenomemon has usually been reported at temperate latitudes, although Haagenson (private communication) has found it over Hawaii. Reverse isentropic air 
parcel trajectories that were calculated by Haagenson, along with ozone concentration data (see below), suggest this mechanism was not the cause of Miami's elevated ozone concentrations in 1978 and 1980 .

Long range transport of ozone within the troposphere is the remaining possible explanation for the high concentrations of ozone observed in Florida during the study period. Although other air pollutants commonly are known to be transported over long distances, ozone has usually been thought to be severely limited with respect to transport due to its high reactivity. The Environmental Protection Agency (1978) categorizes three scales of transport. They are:

1. Urban scale - within cities and a few miles downwind from the source.

2. Meso scale - including land-sea breeze circulation and extending up to one hundred miles downwind from the source.

3. Synoptic scale - longer range transport associated with high pressure systems.

Although the Agency admits to the possibile presence of longrange transport for ozone, it states: "Data suggests but does not prove that most of the oxidant observed in rural and remote areas is transported from cities," (EPA, 1975). The Environmental Protection Agency adds that ozone transport can only occur in the middle to upper troposphere to avoid boundary layer degradation of the ozone. However, in developing regulations the Environmental Protection Agency 
downplays th" impratanc: ut the long range transport air pollutants (EPA, 1979a).

Anderson (1979) has found that ozone can be transported long distances, even at night, without serious degradation if the air mass is kept from contact with the boundary layer, as in the case of transport above inversions. Salop and Maier (1978) found ozone being transported long distances over the ocean into a pristine area of Virginia. The Environmental Protection Agency (1974) reported finding examples of long range ozone transport into Florida during a research project conducted in 1973 . They also reported similar concentrations up and down wind of the Miami urban core. The preliminary data collected in this study suggested that only the third possibility was plausible. Additional data, such as isentropic air trajectories, ozone data from the southeastern United States, and transport time factors all indicate the long range transport of ozone and ozone precursors within the troposphere adequately explains observed conditions. Predictions were made with respect to ozone consentrations in Miami during other time periods. These predictions were then found to agree with collected data. Thus, data is presented below to show that while some of Dade County's ozone during these episodes was of local origin, a significant fraction resulted from the long range transport of ozone. 


\section{I. EXPERIMENTAI PROCEDURES}

Analyses which were preformed routinely to determine the ozone and lead content of surface air samples are described in this section. The method by which air trajectories were calculated is also discribed.

A. OZONE ANALYSIS. The ozone values for Dade County Air samples were obtained from the Dade County Department of Environmental Resources Management (DERM). The ambient air analyzers were two Dasibi 1003AH monitors. The author assisted in the maintenance and calibration of these units, as did other members of the Air Monitoring Group of DERM. Air samples taken in Dade County were analyzed for ozone content by two Dasibi 1003 AH ambient monitors. These monitors continuously determine the concentration of ozone using an ultraviolet photometric detection principle, which is the Environmental Protection Agency's reference method for ozone mearsurement. In this method, air is first drawn through a catalytic ozone scrubber consisting of MnO. The air is then pulled into a folded $71 \mathrm{~cm}$ sample cell. This cell is illuminated by a cold cathode mercury lamp at the $365 \mathrm{~nm}$ absorption line of ozone. The absorbance is automatically read while a pump transfers air through the cell. A solenoid valve is actuated every 25 seconds which changes the flow of air so that the scrubber is bypassed. Otherwise, the path that the unscrubbed air follows is identical to that of the scrubbed air. The second absorbance reading, 
which measures unscrubbed, ozone-laden air, is compared to the first, or ozone free, absorbance reading. This cycle is repeated every 25 seconds.

This particular method of ozone detection is very accurate because the monitor is self-zeroing and selfcorrecting. Since the air follows the same path for both the blank and the sample, any interferences are factored out. The monitor is self-correcting because any contamination or degradation is seen in both sample modes. The monitors used in this study by Dade County were calibrated and checked at routine intervals to insure correct operation per Environmental protection Agency regulations. All monitors that generate data for inclusion in the storage and Retrieval of Aerometric Data (SAROAD) system, which is described below, must meet the stringent quality assurance requirements imposed by the Environmental Protection Agency. These include zero checks, routine calibrations, data reduction checks and the running of standard, blind samples. The Dasibi $1003 \mathrm{AH}$ is calibrated using the Beer-Isambert 1 aw

$$
I=I_{O} \exp (-\alpha L C)
$$

where $I$ is light intensity with ozone present, $I_{0}$ is the light intensity without ozone present, $\alpha$ is the absorbance coefficient for ozone, $L$ is the path length, and $C$ is the ozone concentration.

This equation has been modified to solve for concentra- 
tion, $\mathrm{C}$, at a reference temperature and pressure of $25^{\circ} \mathrm{C}$ and 760 torr respectively. The equation then becomes:

$$
\mathrm{C}=\left[\begin{array}{llllll}
10 & \mathrm{P}_{\mathrm{O}} & \mathrm{T} / & \mathrm{a} L & \mathrm{P} & \mathrm{T}_{\mathrm{O}}
\end{array}\right] \quad \ln \left(\mathrm{I}_{\mathrm{O}} / \mathrm{I}\right)
$$

where $\mathrm{C}$ is the ozone concentration in ppbv, I is the light intensity with ozone present, $I_{O}$ is the light intensity with no ozone, $\mathrm{P}$ is the pressure in the sample cell, $\mathrm{T}$ is the temperature in the sample cell, $\mathrm{P}_{\mathrm{O}}$ is 760 torr, $\mathrm{T}_{\mathrm{O}}$ is $298.16^{\circ} \mathrm{K}$, L is $77 \mathrm{~cm}$, and $\alpha$ is $308 \mathrm{~cm}^{-1} \mathrm{gm}^{-1}$. The sample cell temperature is usually about $12^{\circ} \mathrm{C}$ above ambient due to heating from the eletronics in the monitor.

The monitor is calibrated by allowing it to sample five ozone concentrations and a blank. These concentrations are obtained by passing ozone free air across an ultraviolet lamp to generate ozone. The intensity of the lamp and/or the flow of the diluting air may be varied to obtain the desired concentration. The exact concentration of each calibration point is measured by a master ultraviolet photometer. This master standard is in turn referenced against a "master" master photometer maintained by the National Bureau of standards. The monitor to be calibrated is allowed to sample each known concentration of ozone. The indicated concentration from the monitor is then compared to the known concentration and a calibration curve is drawn. The maximum allowed deviation between the monitor indicated concentration and the known concentration is five percent. The two ozone monitors in Dade County were located 
according to Environmental Protection Agency (1978) guidelines. These guidelines, published in the May 10, 1979 Federal Register, 40 CFR 58, Appendix D, 1 ist different spatial scales or areas of representation. These range from microscale, an area about one hundred miles wide, to regional, which involes several counties. Each scale has specific requirements for monitor siting to insure that all monitors in that scale classification around the country can be compared against each other. The location of Dade County's two monitors are shown in Figure 1.

The Virginia Key site was chosen to sample the supposedly clean air upstream of Dade's urban core when the wind is blowing from what is the predominant southeastern direction. The Thompson site was chosen because of its downwind direction from the urban core and its distance of about 20 miles. This separation allows ozone precursors that were picked up by an air mass during its transit through the polluted urban core time enough to react and form ozone. This process usually takes three to four hours. At typical wind velocities in Dade County during the peak oxidant season an air mass will travel about 20 miles in four hours, hence the Thompson Park Location.

The ozone concentrations measured by the ozone monitors in Dade County are continuously recorded on strip chart recorders. The results are read by trained personnel who convert the raw data into ozone concentrations, expressed as one hour averages. Concentration data are submitted monthly 
to the state of Florida, Department of Regulation, Bureau of Air Quality Management. The data, along with data from all other Florida air monitoring sites, are entered into a computer. A computer printout is then sent to each reporting agency for verification and finally sent to the Environmental Protection Agency Storage and Retrieval of Aerometric Data (SAROAD) system. This is the Environmental Protection Agency's air quality data bank for the entire country. Before any data can be entered they must meet rigorous quality control requirements (Federal Register, 1979). Each reporting agency that desires to enter data into the SAROAD system must prove that the data are legally defensible before they will be accepted. Specific types of monitors, monitor checks, calibrations, siting requirements and data verification procedures are mandated. If the data to be entered does not meet all of these requirements as determined by the Environmental Protection Agency or its designated appointee, that data will not be accepted. This method necessitates much duplication of effort and is time consuming, but insures that the data in the SAROAD system represents an accurate portrayal of the nations air quality. The ozone data analyzed was obtained from the Dade County Department of Environmental Resources Management, the State of Florida Department of Environmental Regulation Bureau of Air Quality Management, and the Environmental protection Agency. The data from all of these sources represents measurements obtained by means of the continuous type 
moniters described above. All data were one hour averages. This amounts to a maximum of 744 data points per site per month. Data were analyzed for a time period totalling approximately 48 site-months or approximately 36,000 ozone concentration data points. The ozone data were reported by many different agencies, thus the values reported are subject to a large number of possible instrument and operator variations. The safeguards of the SAROAD system therefore become very important for establishing data validity. The treatment of this data will be discussed in the next section.

B. LEAD ANALYSIS. The lead and strontium-90 studies were conducted utilizing high volume (Hi-Vol) air filters obtained from the Dade County high volume sampling network. This network is operated by the Department of Environmental Resources Management and consists of eleven Hi-Vol air samplers located within the county. These samplers are used to collect particulate matter for weight determination and lead analysis. The sites, Figure 1, are located in widely varying environments. All sites conform to the strict siting requirements for their spatial scale of representation as described in the May 10, 1979 Federal Register. Most of the samplers in Dade County are sited according to neighborhood scale requirements which represent several square kilometers.

The Hi-Vol air samplers used by Dade County are General 
Metal Works Model 2000 units equipped with a 150 volt motor instead of the standard 110 volt motor. This results in greater dependability and a longer lifetime for the motor. The sampler is housed in a gable-roofed, all-aluminum shelter approximately 1.5 meters high. Below the roof is a horizontal glass fiber filter resting in an aluminum filter holder. Air is pulled around the eaves of the roof and through the 20.3 by $25.4 \mathrm{~cm}$ filter by the Hi-Vol sampler. Typical flow rates for this configuration are 1.1 to $1.4 \mathrm{~m}^{3} / \mathrm{min}$. This flow rate and the shape of the flow streamlines result in particles of 0.1 to 100 microns stokes equivalent diameter being collected. The samplers are operated continously for 24 hours every sixth day, starting at midnight. These samplers constitute the Environmental protection Agency reference method for collecting particulate matter and are used throughout the United States.

The glass fiber filters are supplied by Schleicher and Schull of Keene, New Hampshire, under an Environmental Protection Agency contract. The filters are of borosilicate composition and are designated as S\&S-IHV filters. The results of acceptance testing on these filters by the Environmental protection Agency are shown in Table 1 . These filters are used routinely by Dade County to determine the particulate and lead concentration of the air. Lead analyses were conducted only on filters exposed in Dade County. The lead concentrations were determined on a routine basis. The data for all 11 Dade County collection 
TABLE I .

ACCEPTANCE TEST RESULTS ON

S\&S-1HV FILTERS ${ }^{*}$

Parameter

As

$\mathrm{Sb}$

$\mathrm{Ba}$

$\mathrm{Be}$

$\mathrm{Bi}$

$\mathrm{Cd}$

Co

$\mathrm{Cu}$

$\mathrm{Cr}$

$\mathrm{Fe}$

$\mathrm{Pb}$

$\mathrm{Mn}$

MO

$\mathrm{Ni}$

$\mathrm{Sn}$

$\mathrm{Ti}$

$\mathrm{V}$

Zn

Fluoride

Nitrate

Phosphate

Sulfate

Brittleness

Particle Retention

Flow Rate

Weight Variance

Pin Holes
Specification

100

40

200

5

330

10

30

20

15

200

50

10

15

20

50

15

20

100

100

150

0

300

o failure

99.95\% max.

$1.35 \mathrm{~m}^{3} / \mathrm{min}$

$2.4 \mathrm{mg} \max$

None
Test Result

4.5
8.0
50
165

1.1

13.5

4.9

4.5

90.0

10.0

1.9

2.2

4.5

18.5

0.8

2.2

44.3

16.9

38.4

0.0

27.3

0

$99.97_{3}^{\circ}$

$1.53 \mathrm{~m}^{3} / \mathrm{min}$

$0.34 \mathrm{mg}$

$0.125 / \mathrm{m}^{3}$

* Specifications are given in $\mu \mathrm{g} / \mathrm{filter}$ maximum. Test results are given in $\mu \mathrm{g} / \mathrm{filter}$. 
sites were averaged together. The filters were analyzed for lead by using an ultrasonic digestion technique in combination with an atomic absorption spectrophotometer. A 1.9 by $20.3 \mathrm{~cm}$ strip was cut from the minor axis of the filter. This strip was placed in a $200 \mathrm{ml}$ beaker and covered with about $15 \mathrm{ml}$ of $\mathrm{HNO}_{3}$. The beaker was then placed in an ultrasonic bath for 30 minutes. The liquid in the beaker was decanted into a $100 \mathrm{ml}$ volumetric flask. The filter was then washed and the washings transferred to the flask. The filter was covered with deionized water and set aside for 30 minutes. This liquid was decanted into the $100 \mathrm{ml}$ volumetric flask. The volume was brought to $100 \mathrm{ml}$ with deionized water. The solution was then analyzed with a Perkin Elmer model 380 atomic absorption spectrophotometer, using the $283.4 \mathrm{~nm}$ lead 1ine. A zero concentration reagent blank and a 5.00 ppmv solution were analyzed after every eight samples to verify the calibration of the spectrophotometer. Additional quality assurance is obtained by introducing blind samples and known concentration samples at random intervals. The Environmental Protection Agency conducts performance audits twice yearly by providing six filter strips with known concentrations of lead for analysis. The concentration of lead in the atmosphere is calculated using the equation:

$$
\mathrm{Pb}_{(\mathrm{air})}=1200(\mathrm{~Pb} \text { analysis }) / \mathrm{V}
$$

where $\mathrm{Pb}$ (air) is the concentration of lead in the air 
expressed as $\mu \mathrm{g} / \mathrm{m}^{3}, \quad 1200$ is a conversion factor which accounts for using $1 / 12$ of the filter and converting ppmv to $\mu \mathrm{g} / \mathrm{m}^{3}$. V is the total volume of air to pass through the filter.

C. STRONTIUM-90 ANALYSIS. The filters analyzed for Sr-90 were selected from those that had been exposed as close as possible to a period of high ozone. Blank filters were included for background corrections. The extraction procedures for Sr-90 were first developed by Reiter et al. $(1977)$

The procedure used in this study was initially developed by poet et al. (1972). This technique was revised in order to cope with the glass fiber material and the expected very low Sr-90 concentrations. The counting was done using: a procedure described by Moore et al. (1977). The sample was placed between two thin-walled flow counters which were in turn surrounded by anti-coincidence counters. This arrangement was surrounded by $15 \mathrm{~cm}$ of steel shielding. Almost a 4 pi geometry can be achieved by this configuration with a backgroound level of only 0.25 to 0.60 counts per minute. A major problem was found to be the dissolution of all silica in the filter material so as not to entrap any strontium. This latter problem could not be solved in a satisfactory manner, thus results on the Sr-90 analysis were inconclusive and are not presented. 
D. AIR TRAJFCTORY ANALYSIS. A vital portion of the research for this thesis concerned the calculation of air parcel trajectories. These were calculated by Dr. Phil Haagenson at the National Center for Atmospheric Research in Boulder, Colorado. Trajectories were chosen at an altitude or atmospheric pressure level just above the surface boundary layer. This eliminated effects from buildings, trees and other surface features. The trajectories were made using isentropic analysis techniques described by Haagenson and Shapiro (1979). They found the most accurate method to analyze air flow was on constant potential temperature or theta surfaces. The reason for this is that air movement occurs on surfaces closely corresponding to isentropic surfaces. The airflow that is usually described by quasi-horizontal surfaces, as on an isobaric map, works only in theory and does not accurately portray a three dimensional troposphere. 


\section{IJI. PRESENTATION AND DISCUSSION OF DATA}

Data is presented for the time periods October, 1978; June, 1980; July, 1980; and August, 1980. This data is divided so as to present five distinct time periods with respect to ozone concentrations in Miami and the Southeastern United States. The data were obtained and met the quality assurance requirements as described in the previous section. The data as received consisted of hourly averages reported by individual stations. Where multiple stations existed in one county the arithmetic mean of the hourly averages from those stations were calculated. An average daily ozone concentration was then computed. The daily ozone averages for each county were then plotted versus the day of the month. The resulting ozone concentrations displayed considerable variance and trends were not easily discerned. Three day running averages were then plotted. This averaging method lowers maximum values and raises minimum values but results in graphs in which it is much easier to discern ozone concentration trends. These three day running averages versus date are presented. In order to enhance readability, the data from states with many stations has been divided so that only three or four sites appear on each graph.

The lead data is presented on graphs which also contain daily average ozone concentrations in Miami. This type of graph shows possible correlations between ambient lead levels and ozone concentrations. Due to a lack of major 
stationary sources in Dade County, it is known that almost all locally produced air pollution originates from vehicular sources. In addition to ozone, lead is also a major component of air pollution due to vehicles. One way to determine if Miami was causing its own polluted air was to check for increased concentration of lead. If the high levels of ozone resulted from local vehicular sources, there should be a corresponding increase in lead concentrations. The isentropic air trajectories presented are representative of twelve hour time increments as shown by the arrowheads and are calculated back from the final air mass location shown. Data for the five distinct episodes are discussed below.

A. AUGUST $18-24,1980$ EPISODE. Dade County experienced elevated concentrations of ozone during the period of August 18-24, 1980 at both the Virginia Key and Thompson Park sites. Figure 2 shows the ozone and the lead concentrations in Miami for the month of August. It is evident that during the August 18-24 time period the ozone concentration is elevated but the lead concentration is depressed. This lack of correlation between the lead and ozone concentrations indicates the ozone was not generated locally.

The daily running averages for ozone in the three southeast Florida counties are shown in Figure 3 . It is perhaps not surprising that all three counties exhibit the same general pattern of ozone levels as they are classified by the Environmental Protection Agency as being in the same 


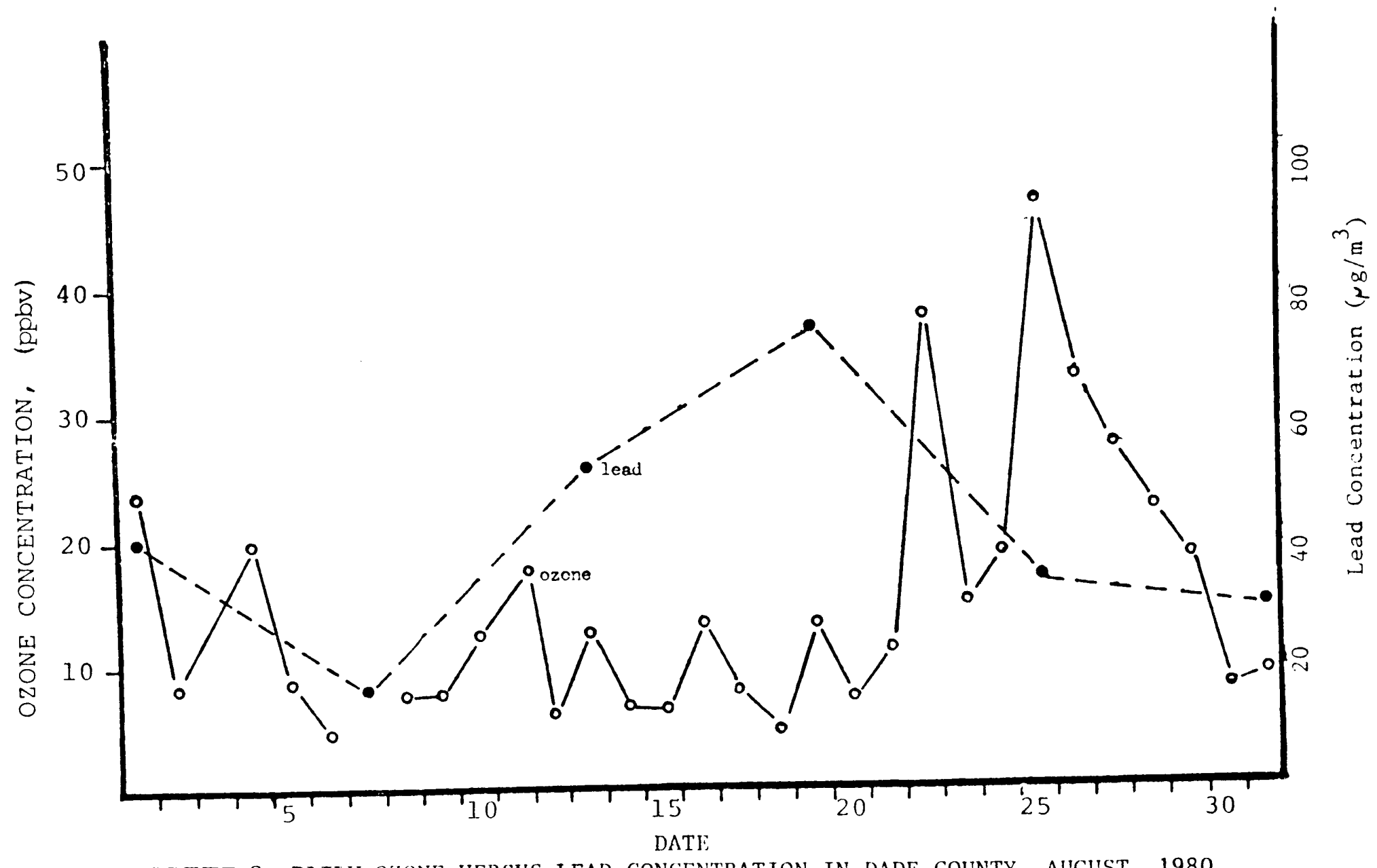

FIGURE 2: DAILY OZONE VERSUS LEAD CONCENTRATION IN DADE COUNTY, AUGUST, 1980 


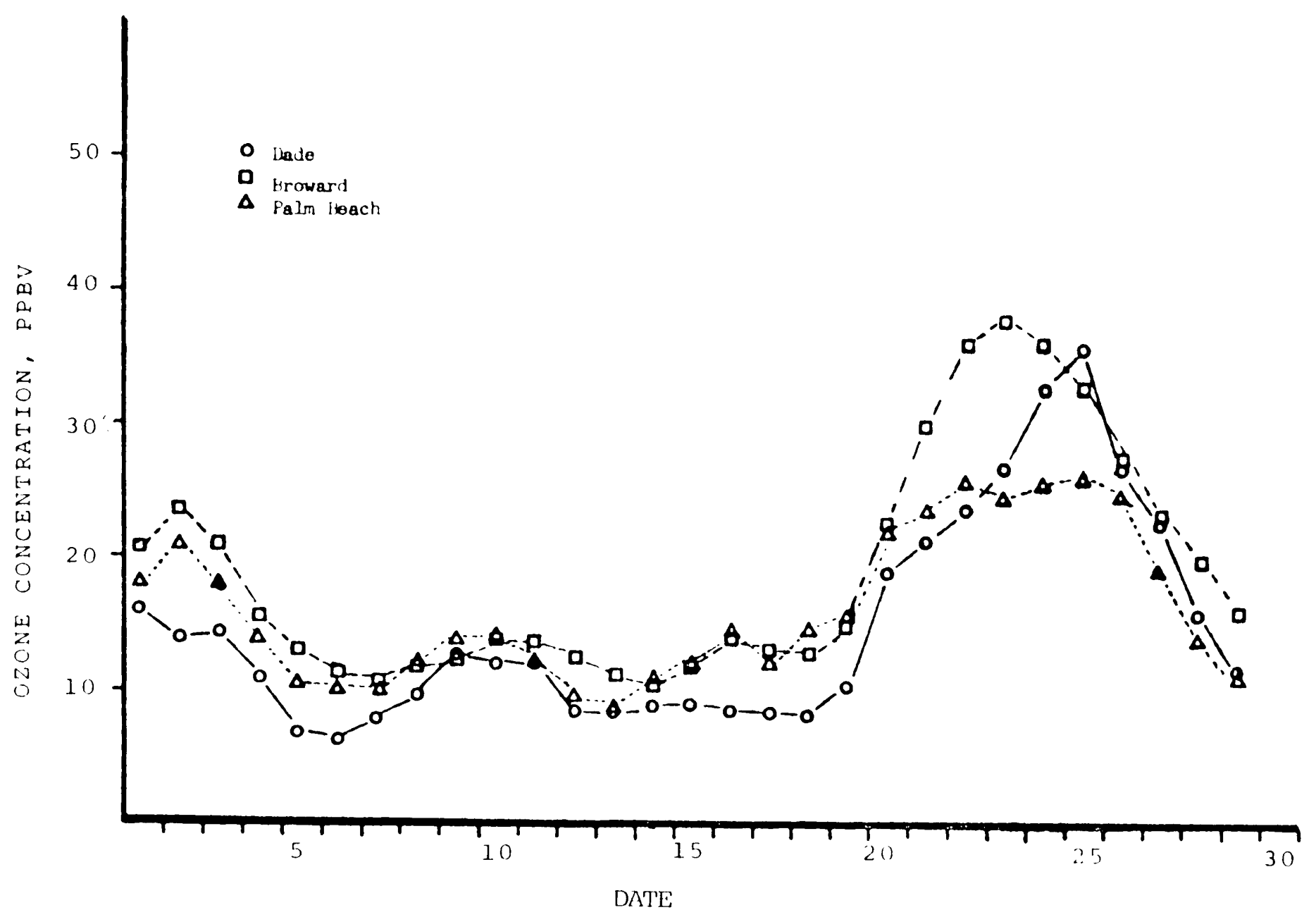

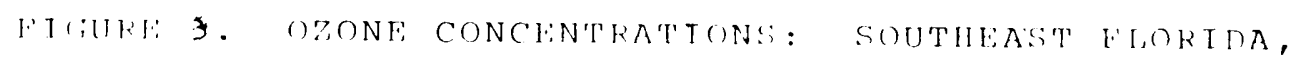
AUGUST, $] 980$. 
air shed. All three counties are coastal and all three have ozone sampling sites similar to that in Dade County, one coastal site and one inland site. Elevated ozone levels were recorded at all sites.

This general condition extended northward for this time period. The data for the Tampa Bay Area, which consists of Hillsborough and Pinellas Counties, are shown in Figure 4. There is a pattern similar to that in South Florida. Figure 5 Shows the three day running averages for Upper Florida. Again there is a similar pattern. All areas experienced a minimum ozone concentration about August 15 and a maximum ozone concentration about August 21. Ozone levels began to increase slightly earlier in the Upper Florida region and last at the South Florida sites. In general the ozone concentration appeared to increase as latitude increased. In order to ascertain if this phenomenon took place over a larger area, data were plotted for Alabama, Georgia and South Carolina. These three day running averages are shown in Figures 6 through 10. Once again the same general patter appears with the maximum ozone concentration occurring about August 20. The ozone concentration also increased with latitude. It is also seen in the case of the South Carolina sites that the ozone averages are more variable. Greater variability in the concentration of air pollutants usually occurs as a varying source or origin is approached. As the diffusion time-distance relationship increases, the extreme values of concentration are averaged out and a better 


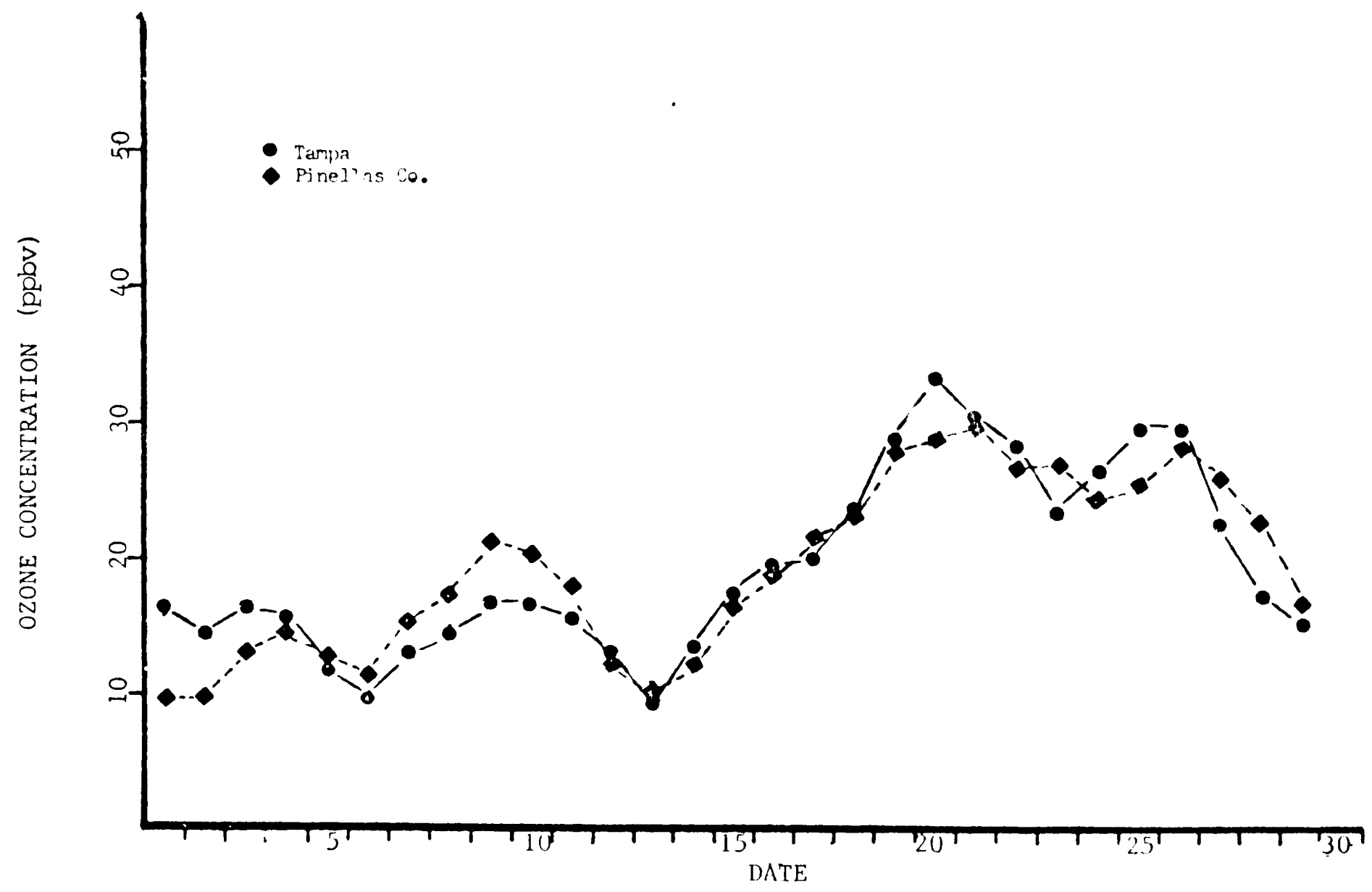

FIGURE 4: OZONE CONCENTRATIONS: TAMPA BAY AREA, AUGUST, 1980 


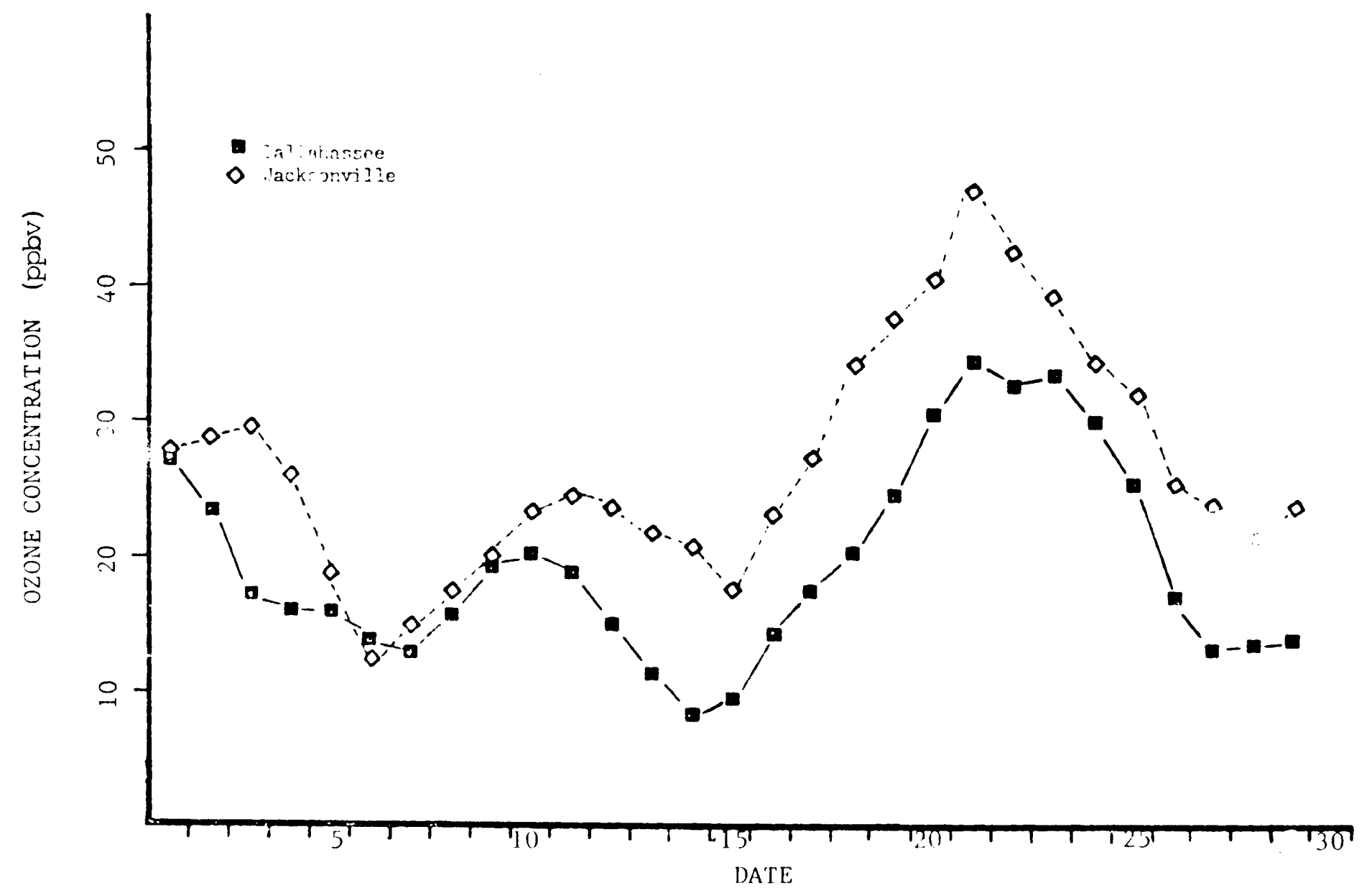

FIGURE 5: OZONE CONCENTRATIONS: UPPER FLORIDA, AUGUST, 1980. 


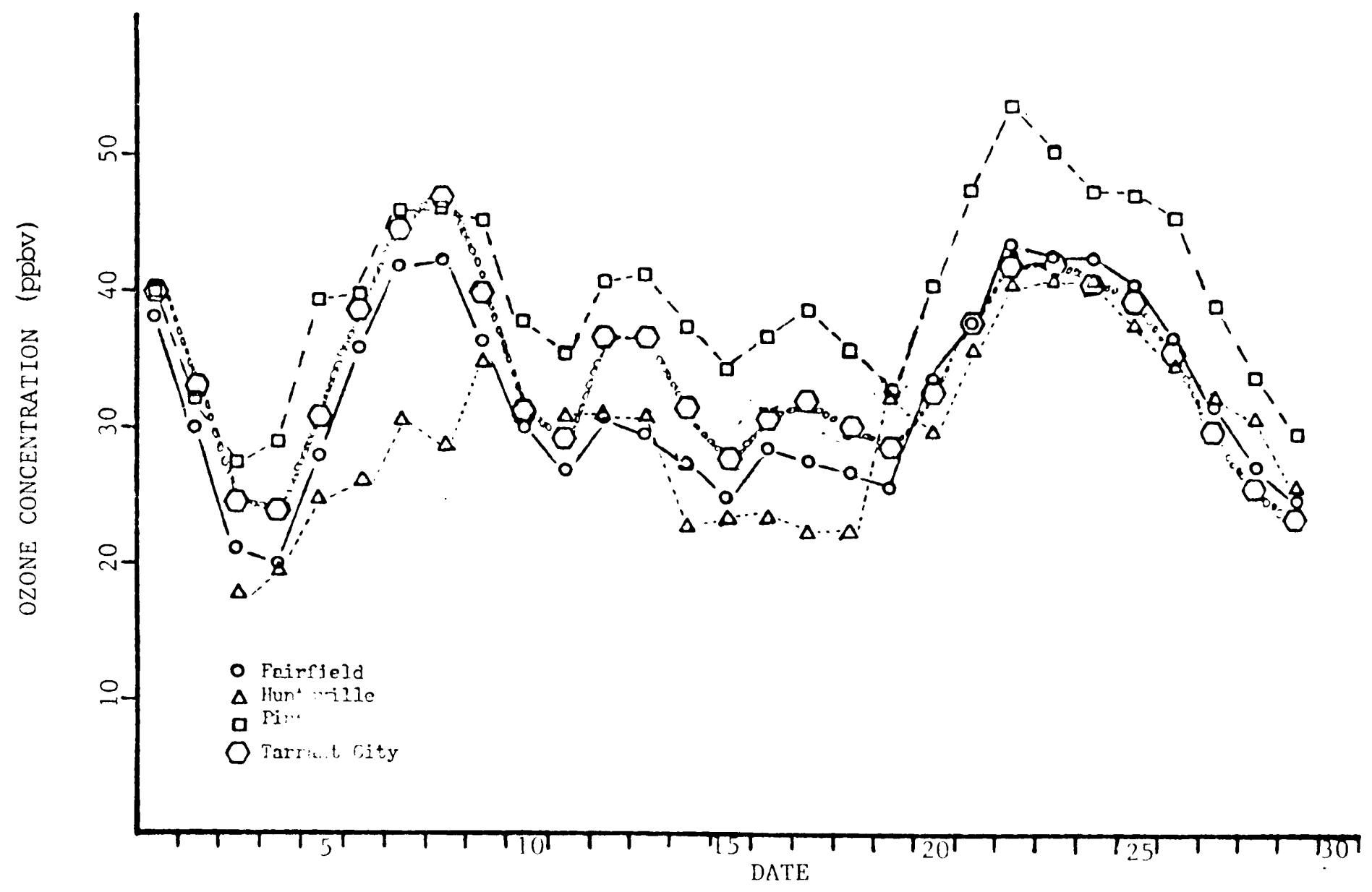

FIGURE 6: OZONF, CONCENTRATIONS: ALABAMA, AUCUST, 1980. 


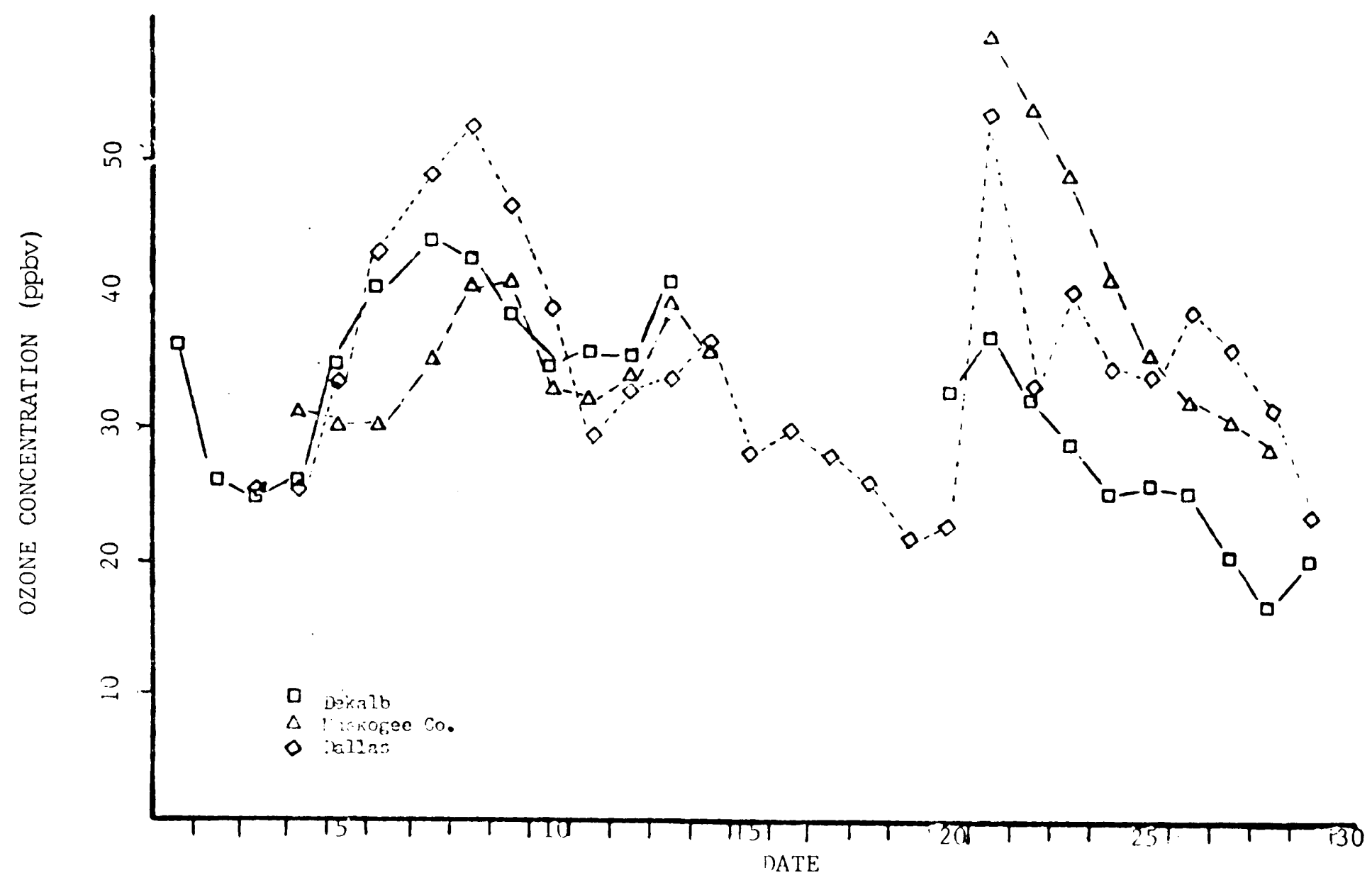

FIGURE 7: OZONE CONCENTRATIONS: GEORGIA, AUGUST, 1980 


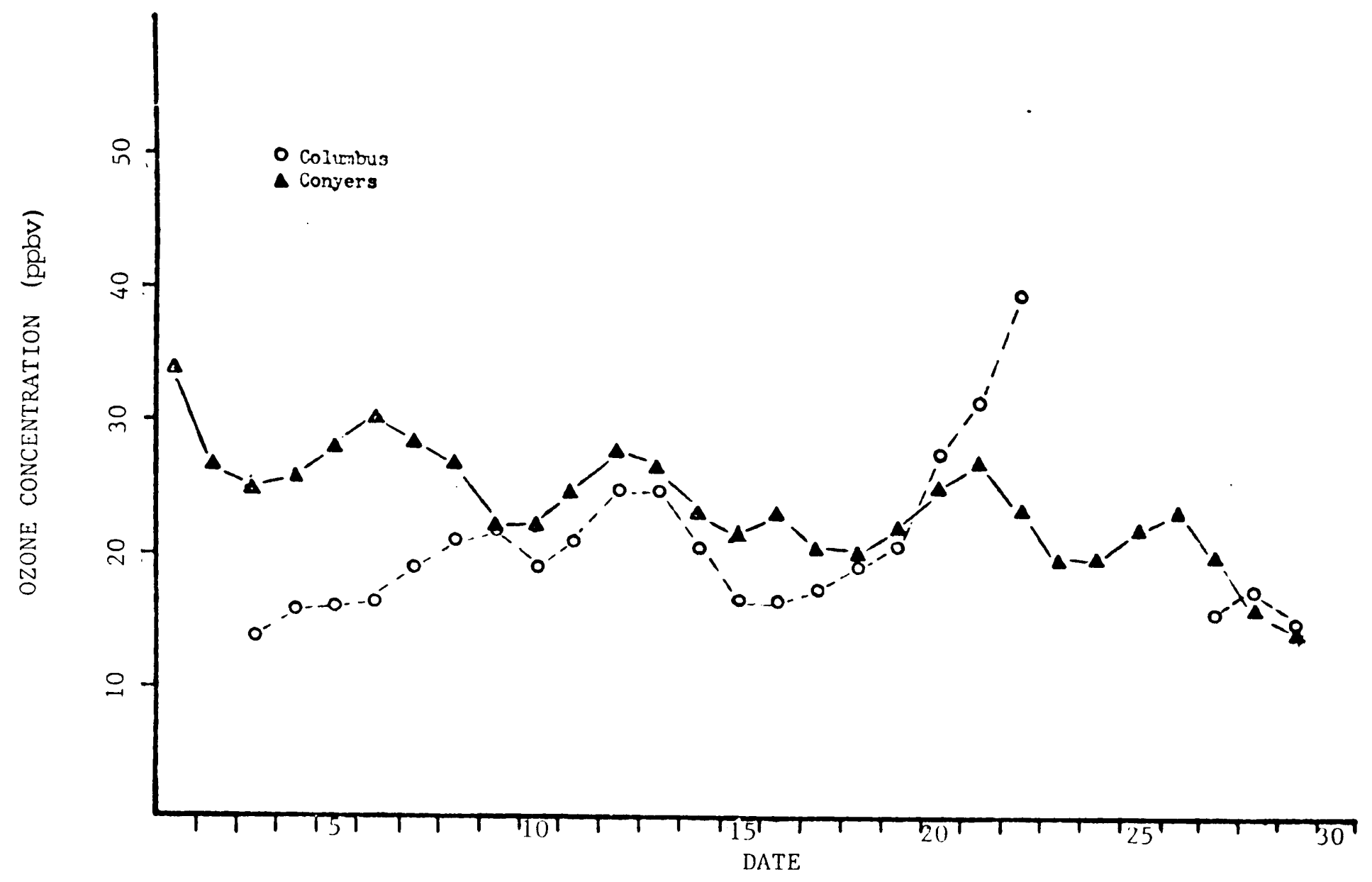

FIGURE 8: OZONE CONCENTRATIONS: GEORGIA, AUGUST, 1980. 


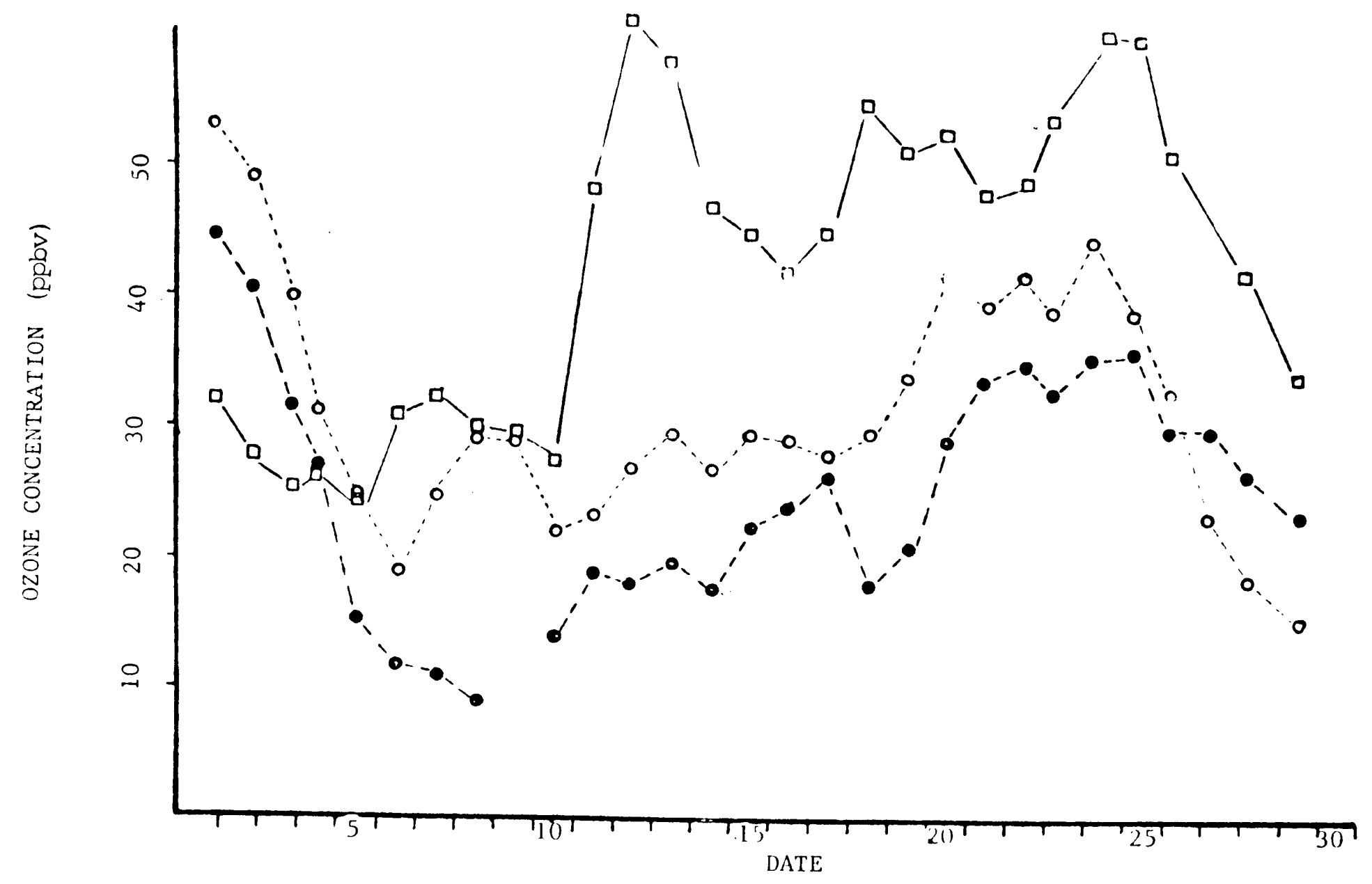

FIGURE 9: OZONE CONCENTRATIONS: SOUTH CAROLINA, AUGUST, 1980. 


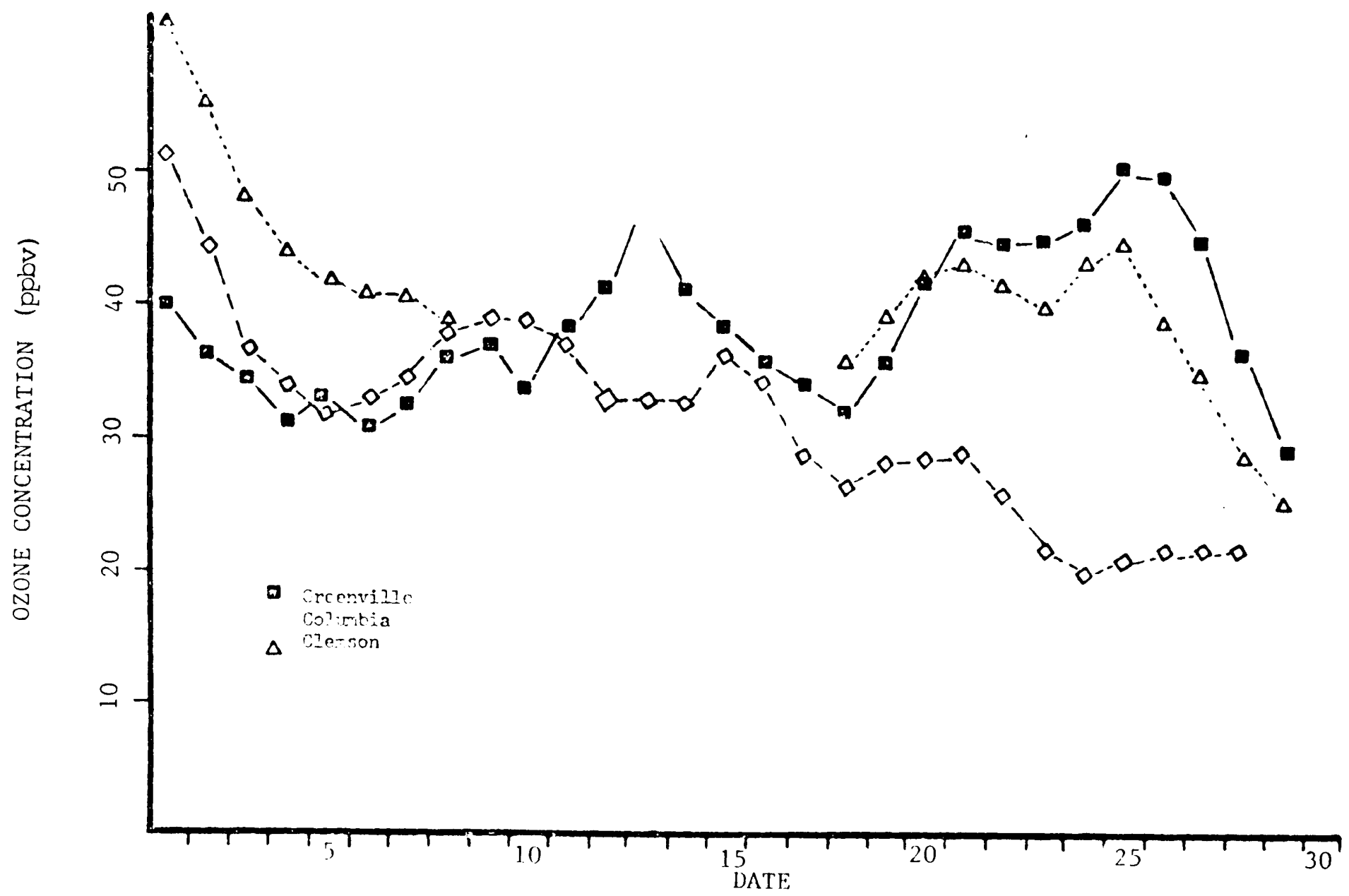

FIGURE, 10: OZONE CONCENTRATIONS: SOUTH CAROLINA, AUGUST, 1980 
defined pattern with lower average concentrations is seen. Thus it appears that the source of a portion of the ozone in South Florida originates over the Southeastern United States. Weather patterns for this time period are shown in Figures 11 through 14. There was a persistant high pressure area over the Southeastern United States. This is a typical weather pattern which has been well documented. Altshuller (1978) of the Environmental Protection Agency notes that this area of the country is subject to more days of persistant high pressure than any other region in the country, especially during the period from May through October. He additionally noted that ozone appears to circulate around this weather pattern. Further support for the transportation of ozone is shown in the reverse isentropic trajectory shown in Figure 15. This shows that the air mass found over South Florida came from the area of Louisiana, Alabama and Tennessee. It appears probable that ozone and its precursors were generated in those areas and transported southward. Additional ozone and precursors may have been picked up by the air mass on its way southward. Thus for this episode the available data strongly indicates that the bulk of the ozone in Miami was not generated locally, but was transported through the troposphere from other areas. This transport appears due to the circulation pattern set up around a high pressure weather system.

This effect does not appear to be an isolated case as shown by the episode which follows. This pattern while 


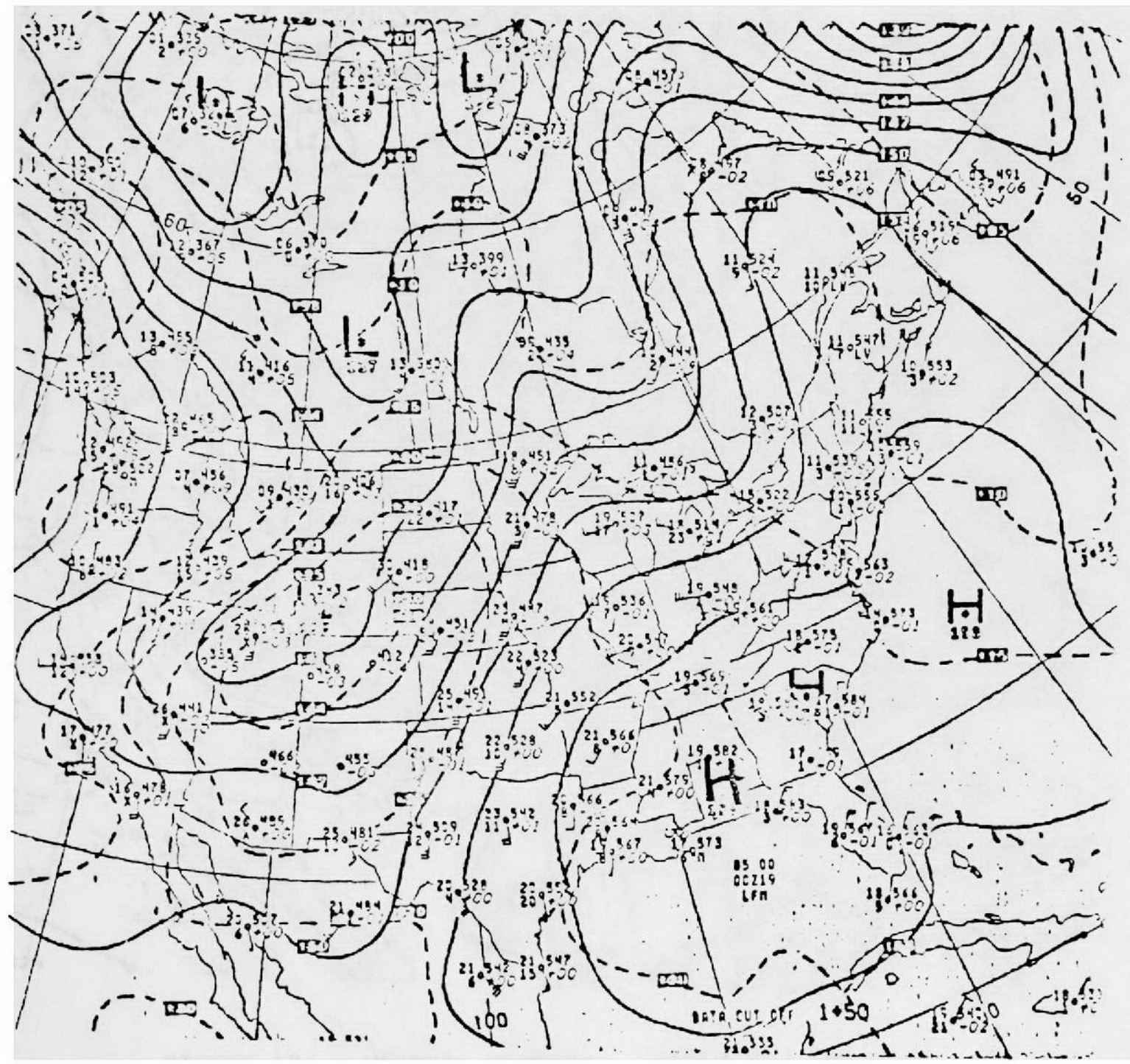

FIGURE 11: WEATHER PATTERN: AUGUST 19, 1980 


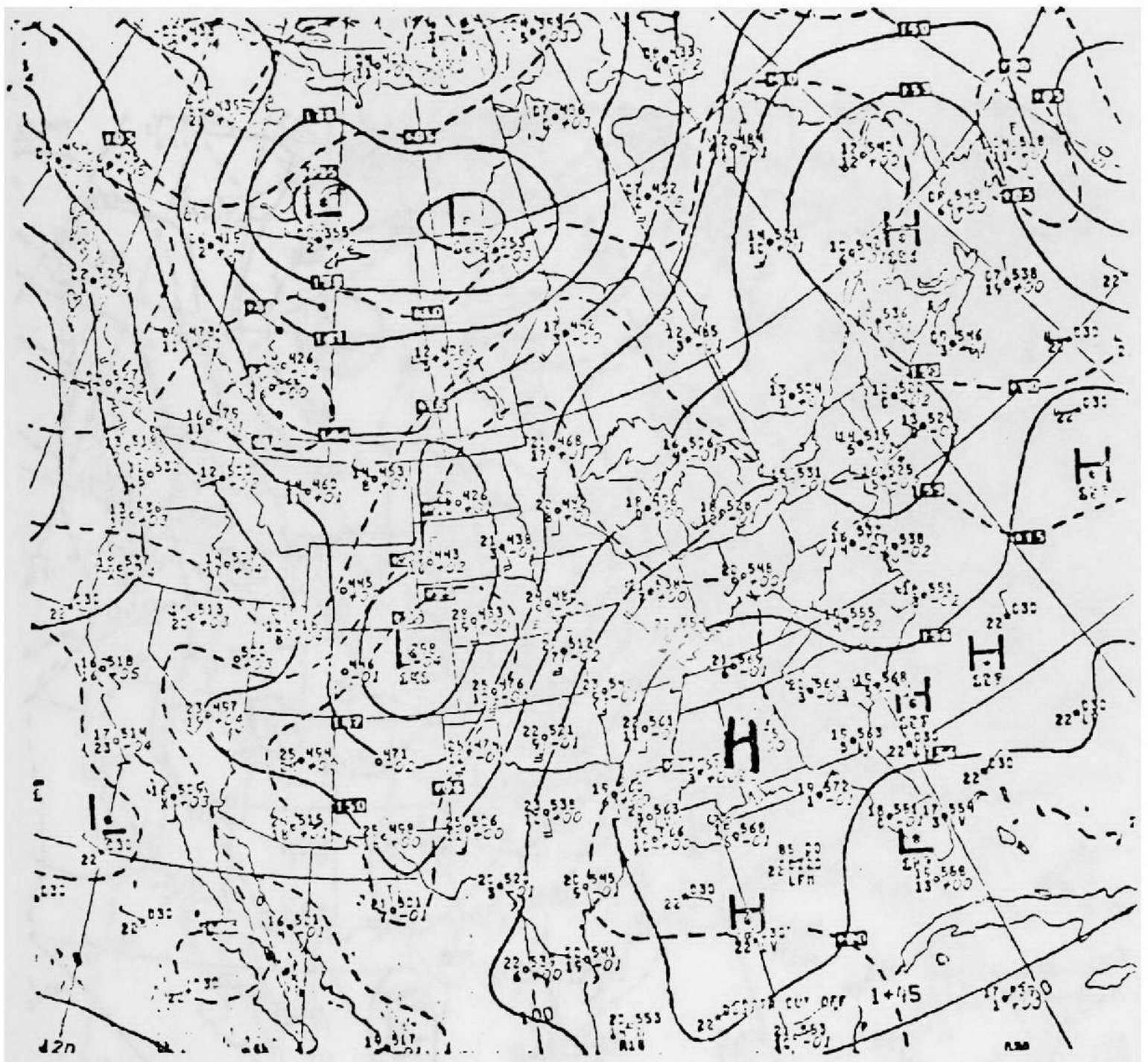

FIGURE 12: WEATHER PATTERN: AUGUST 20, 1980. 




FIGURE 13: WEATHER PATTERN: AUGUST 21, 1980 


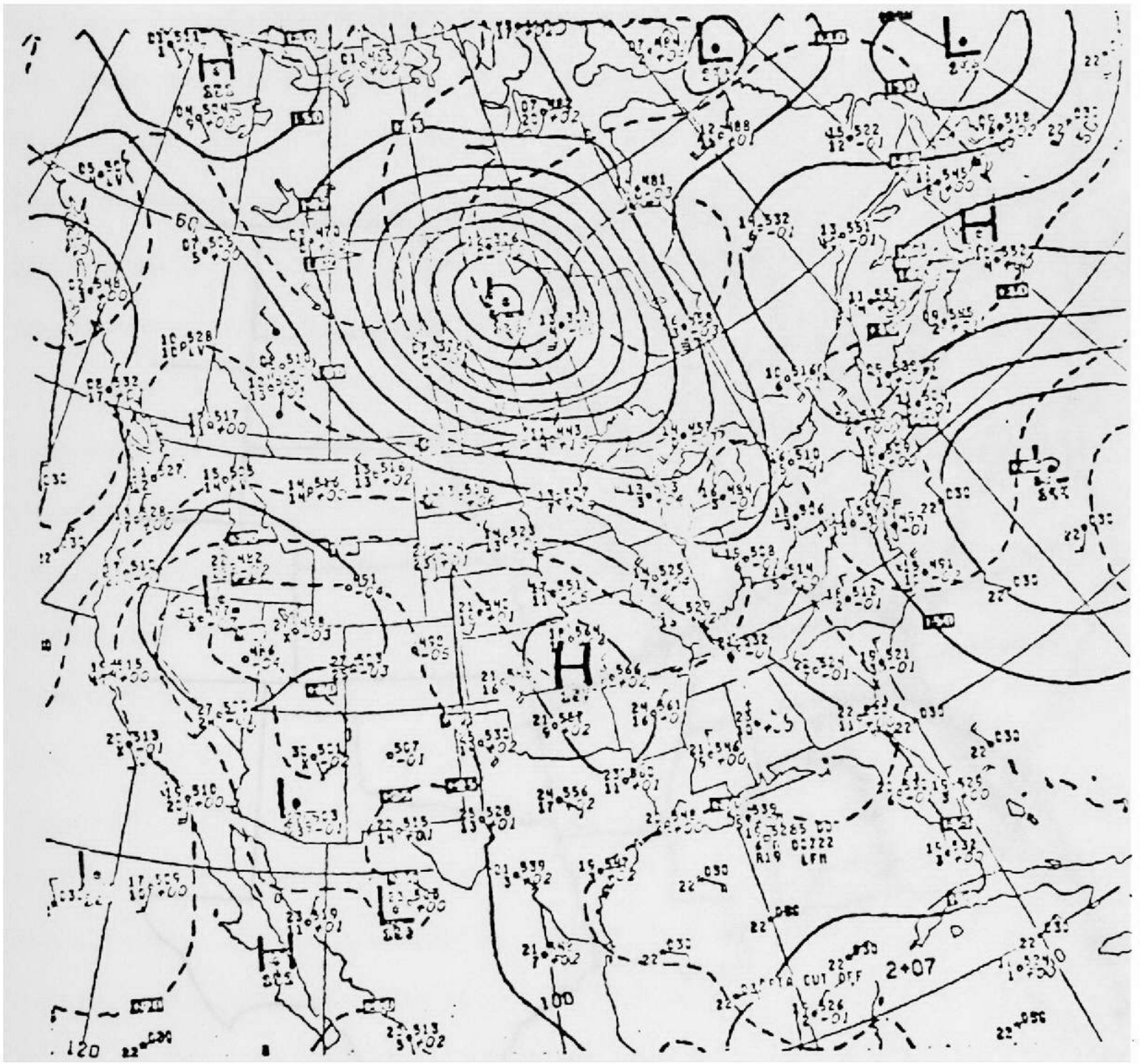

FIGURE 14: WEATHER PATTERN: AUGUST 22, 1980 


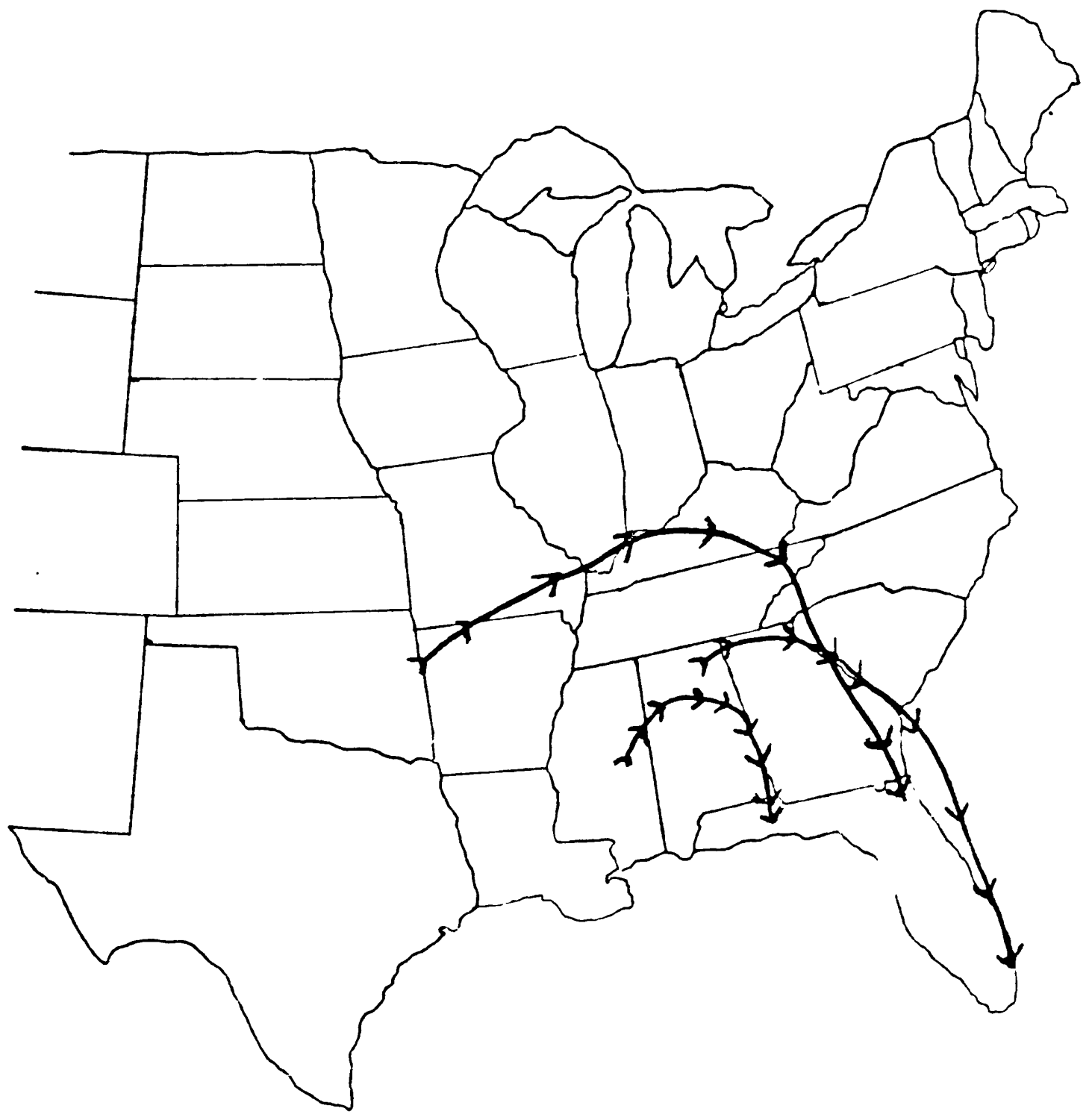

FIGURE, 15: ISENTROPIC TRAJECTORIES. AUGUST 18-24, 1980 EPISODE 
persistant is undoubtedly of varying intensity.

B. OCTOBER 16-18, 1978 EPISONE. A similar pattern occurred during this episode except that while ozone concentration levels were high in Dade County they did not exceed the National Air Quality Standards. Figure 16 shows that once again the ozone concentrations are elevated while the lead concentration between October 15 and 21 is low. Again this negative correlation between the lead and ozone concentrations indicates the ozone was not generated locally.

During this month only Dade County was reporting ozone concentrations in South Florida. These three day running averages are shown in Figure 17. Values during the October 16-18 period are definitely elevated. Figure 18 shows the three day running average of ozone concentrations in the Tampa Bay area. This figure shows a rapid increase in the ozone values during the same time period as in South Florida. The Upper Florida averages, Figure 19, are similar to those in Tampa and South Florida, but of even greater magnitude. These averages remained elevated some what longer, decreasing slightly on October 20 and the sharply on october 24. The ozone concentrations in Georgia are shown in Figure 20.

The weather map for this time period, Figure 21, shows a large low pressure area centered over the Great Lakes and a high pressure area over the Bahamas. The effect of this weather pattern is shown in Figure 22. Subsiding air from 


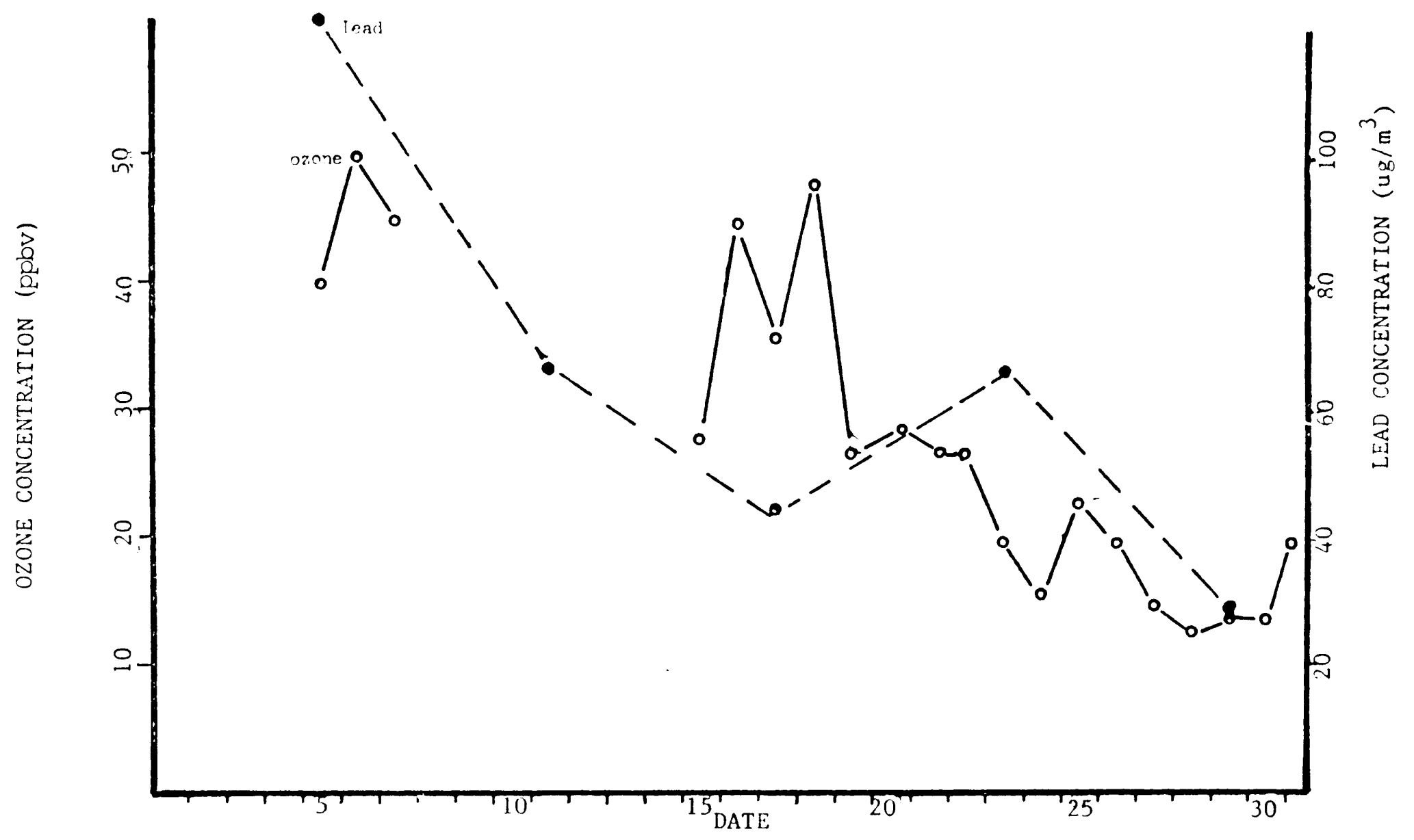

FIGURF 16: DAILY OZONE AND LEAD CONCENTRATIONS: DADE COUNTY, OCTOBER, 1978. 


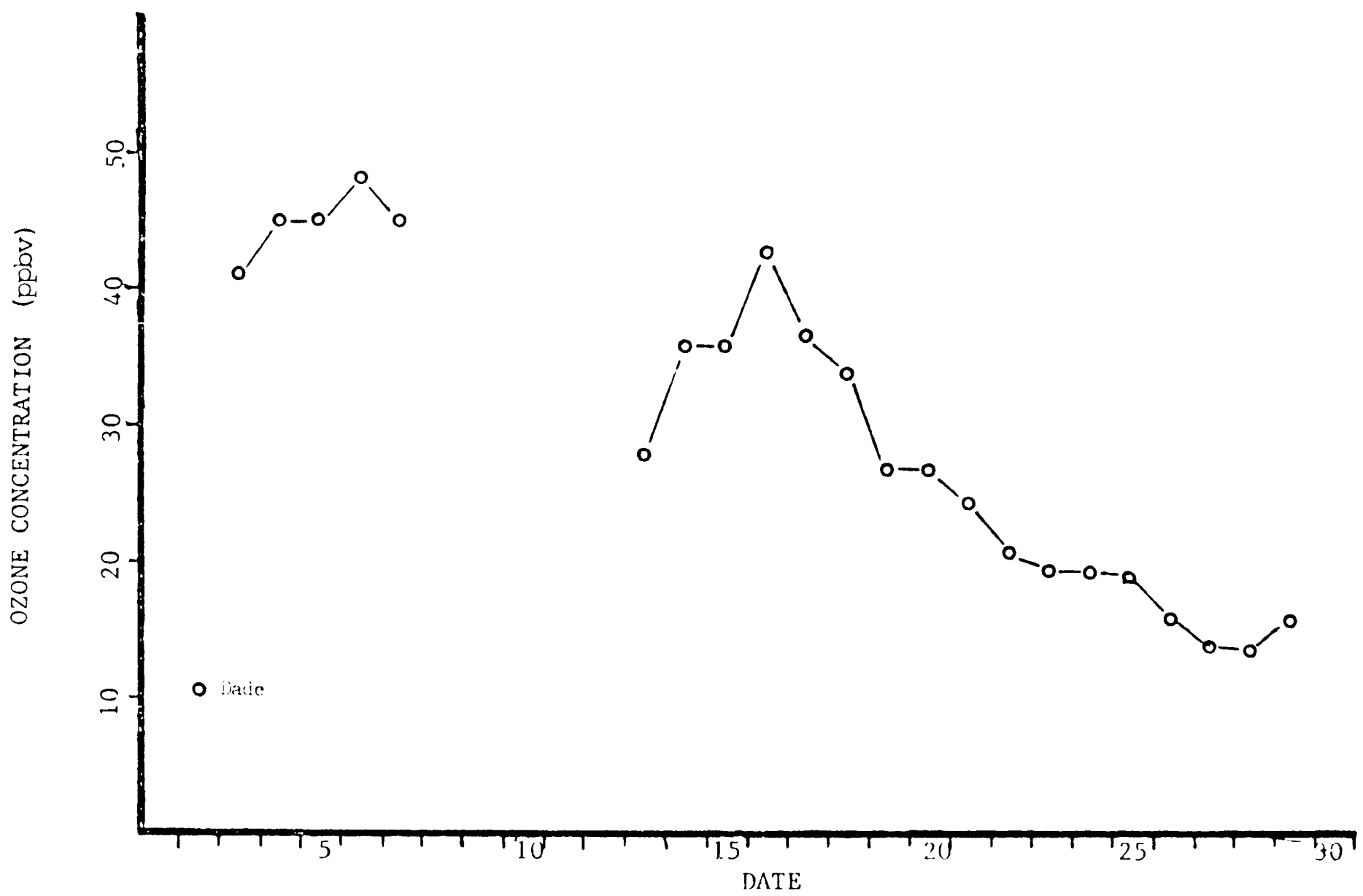

FIGURE 17: . OZONE CONCENTRATIONS: DADE COUNTY, OCTOBER, 1978. 


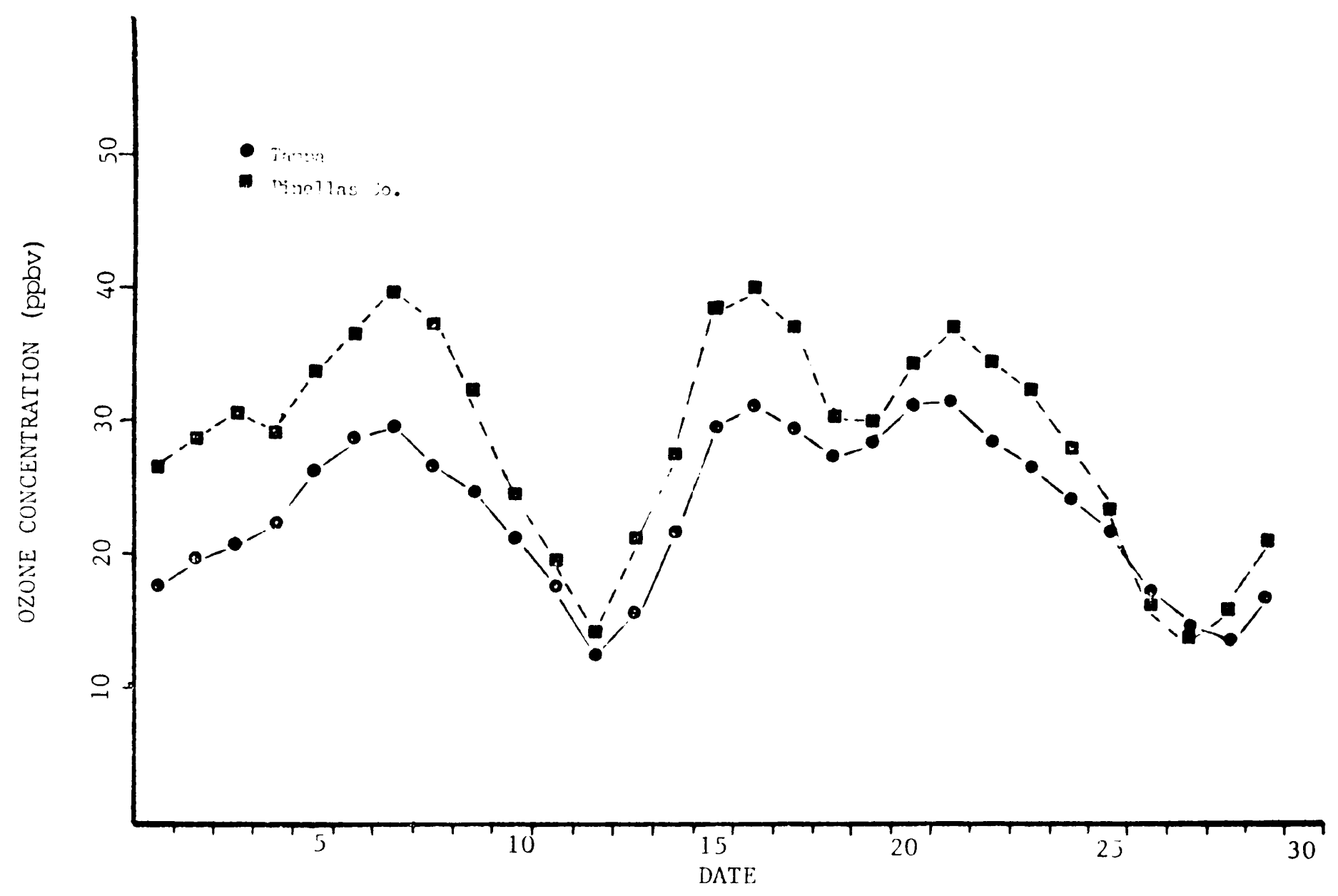

FIGURE 18: OZONE CONCENTRATIONS: TAMPA BAY AREA, OCTOBER, 1978. 


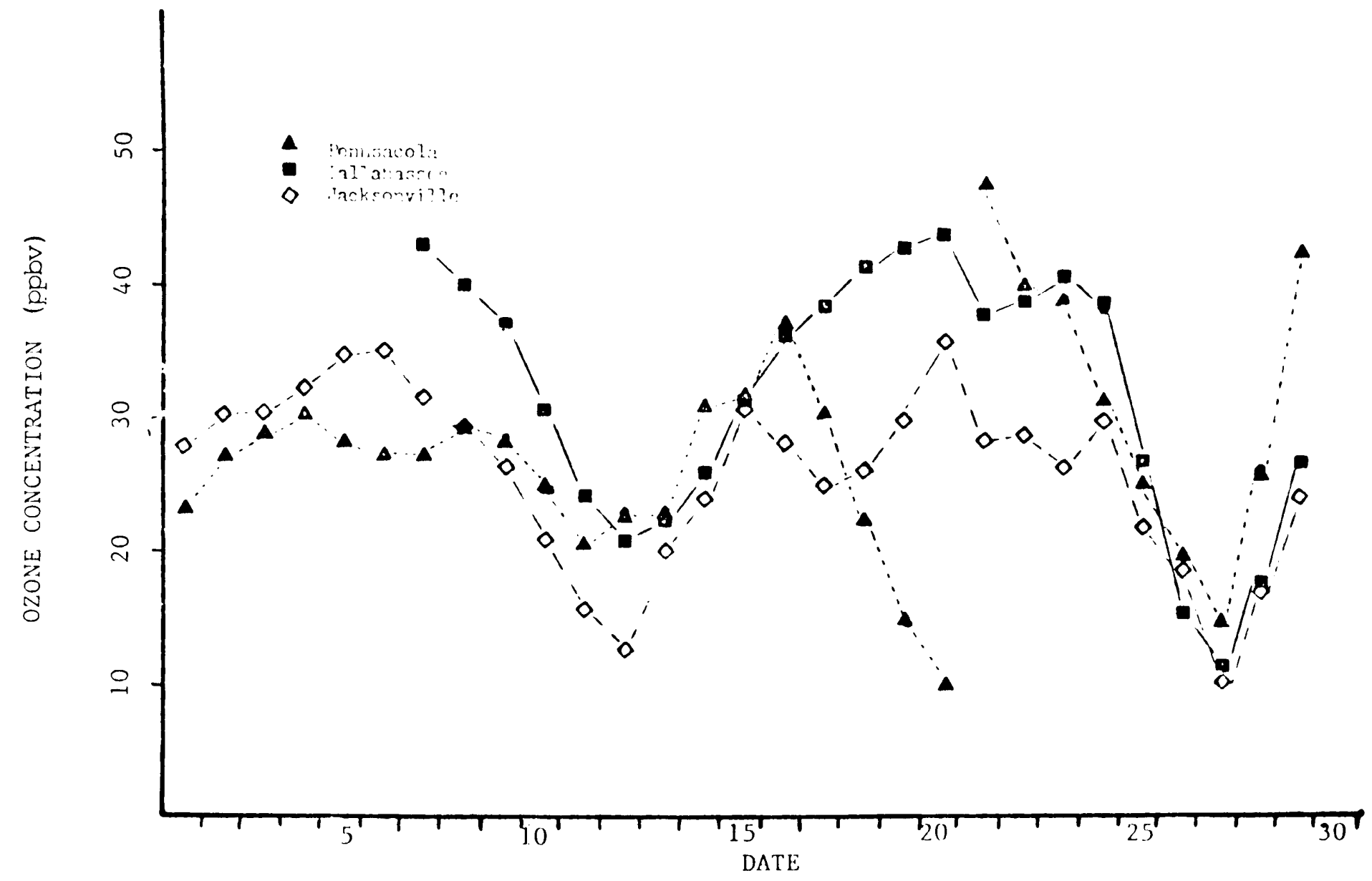

FIGURE 19: OZONE CONCENTRATIONS: UPPFN FLORIDA, OCTOBER, 1978. 


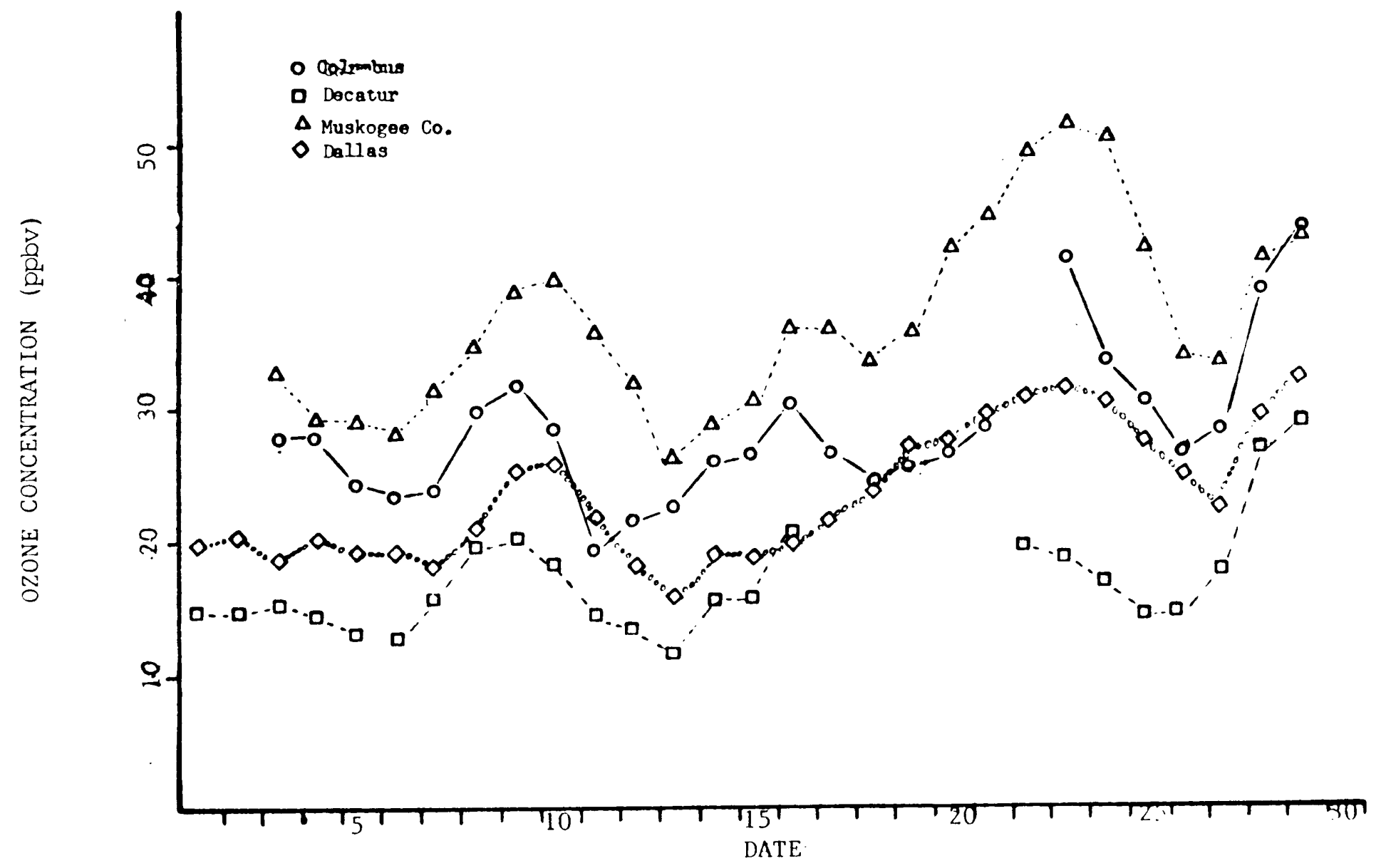

FIGURE 20: OZONE, CONCENTRATIONS, GEORGIA, OCTOBER, 1978. 


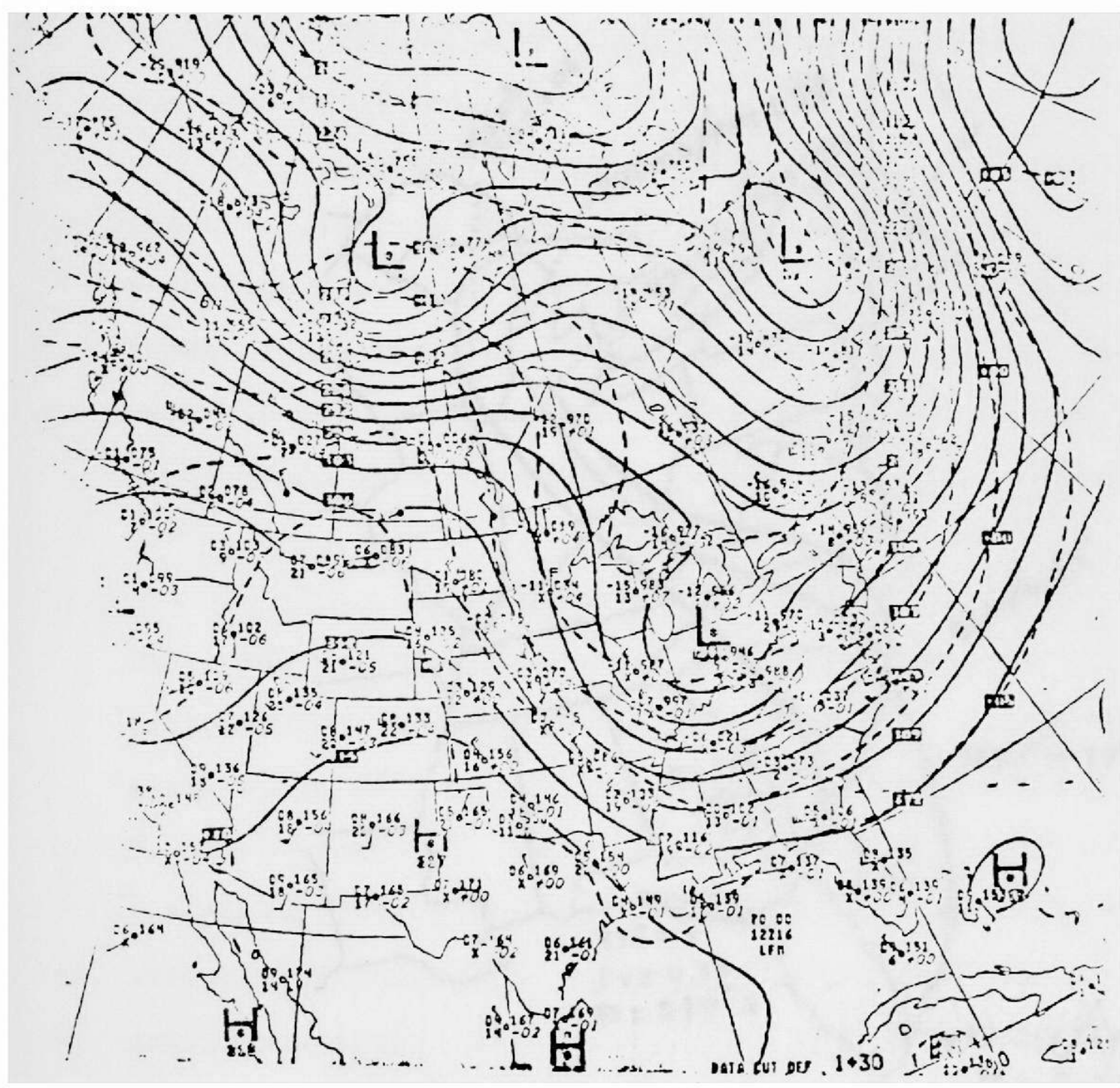

FIGURE 21: WEATHER PATTERN: OCTOBER 16, 1978. 


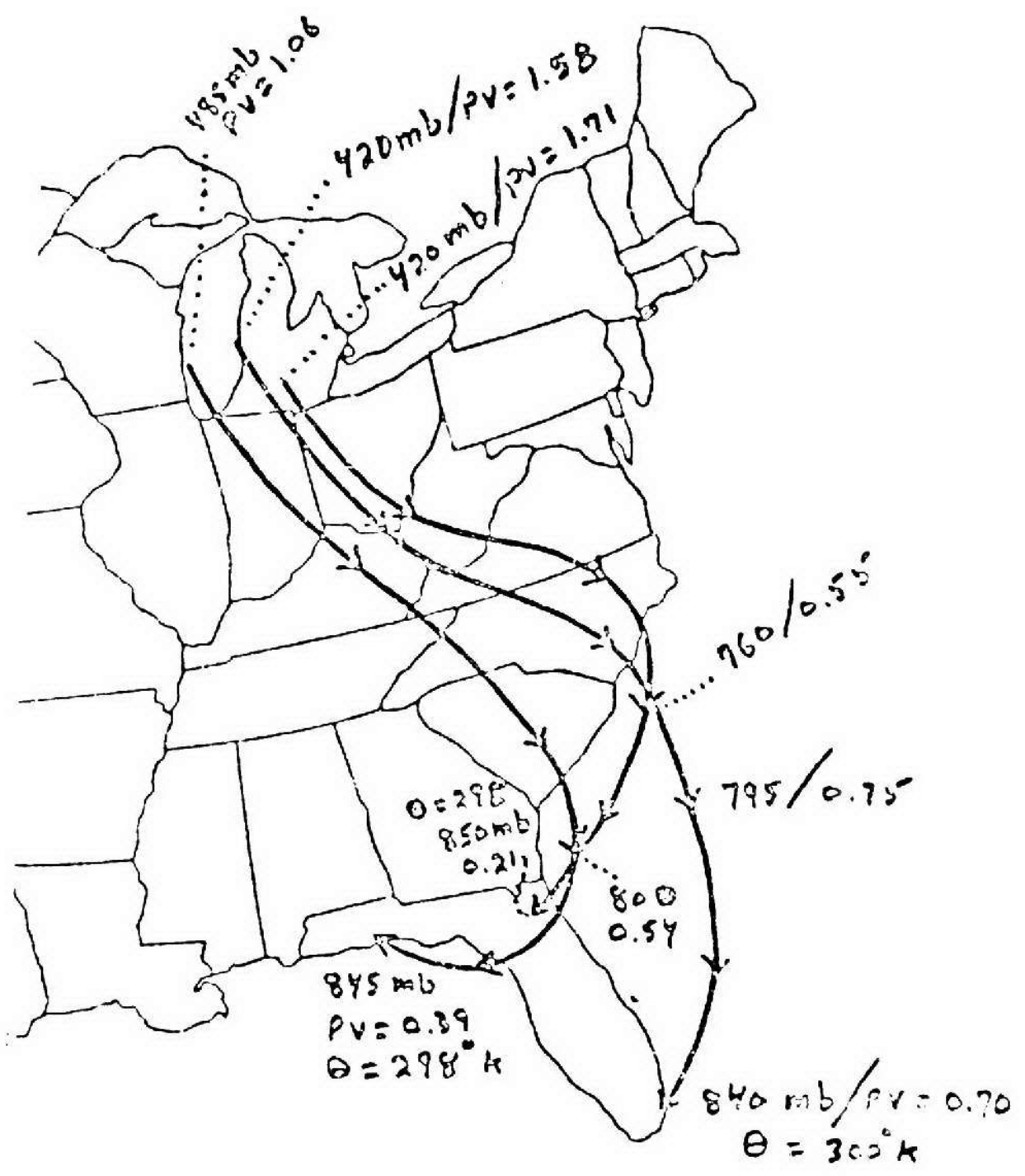

FIGURE 22: ISENTROPIC TRAJECTORIES: OCTOBER 16-18, 1978 EPISODE. 
the stratosphere is transported over the Southeastern United States and the Atlantic Ocean and then back into Florida. The air mass impacting Florida therefore skirts Georgia. The transport of the air mass over the Atlantic Ocean apparently reduces the intensity of the scavenging effects, thus explaining the slightly higher readings in North Florida as compared to Georgia.

This analysis suggests that ozone laden air was transported into Dade County and not generated locally during this time period. Although Northern Florida reported violations of the National Ambient Air Quality standard, the air mass did not have a sufficient concentration of ozone and ozone precursers to cause violations in Dade County.

C. AUGUST $7-10,1980$ EPISODE. This time period indicates how a differing weather pattern can alter the tranport pattern shown above. North Florida had the same pattern while South Florida had no elevated ozone concentrations. Figure 2 shows both the ozone and lead concentrations to be low during this period. The Southeast Florida running average remained quite low not only throughout this time, but until August 19. This is shown in Figure 3. The Tampa Bay area, Figure 4, begins to show an increase in ozone concentration approximately August 7 with a decline about August 10. Upper Florida, Figure 5, shows the same pattern, but reaches higher concentrations. In Florida, therefore, the ozone concentrations increased as latitude increased. Data 
from other southeastern states shows this trend continues outside of Florida. Ozone concentrations for Alabama, shown in Figure 6, follows the same trend as in Figures 4 and 5 . Not only are the average ozone concentrations higher but the increase in ozone concentration occurs earlier resulting in an earlier peak concentration. Figures 7 and 8 show the continuation of this trend in Georgia. South Carolina, Figures 9 and 10 , while experiencing relatively high ozone concentrations, did not follow a distinct trend. The isentropic trajectory analysis, Figure 23, shows that North Florida was being impacted by both a continental air mass and maritime air while South Florida was experiencing air coming in from the Caribbean. Thus while the same transport pattern is seen in North Florida, it did not continue down the peninsula.

D. JUNE $7-10,1980$ EPISODE. This episode is similar to the one above. During this time period all of Florida except South Florida experienced very high concentrations of ozone. Once again Dade County had low concentrations of both ozone and lead, Figure 24. The ozone three day running averages show elevated ozone readings in other South Florida areas peaking on June 5 , then declining rapidly to June 10 , followed by another rise (Figure 25). The Tampa Bay area, Figure 26, had a similar pattern, however the maximum and minimum were less pronounced that in South Florida. The situation in Upper Florida for this time period is very 
55

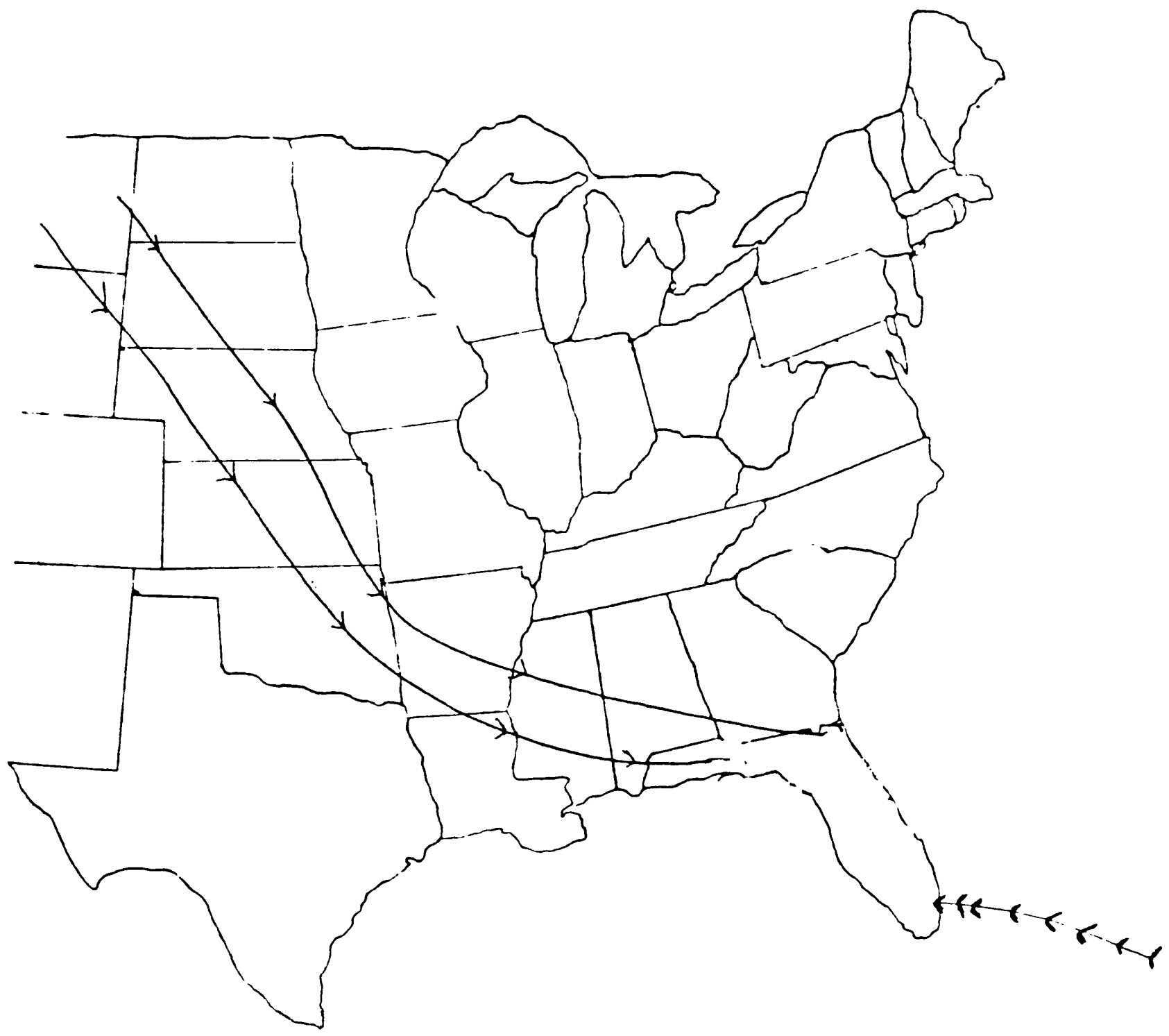

FIGLKE 23: ISENTROPIC TRAJECTORIES, AUGUST 7-10, 1950 EPISODE. 


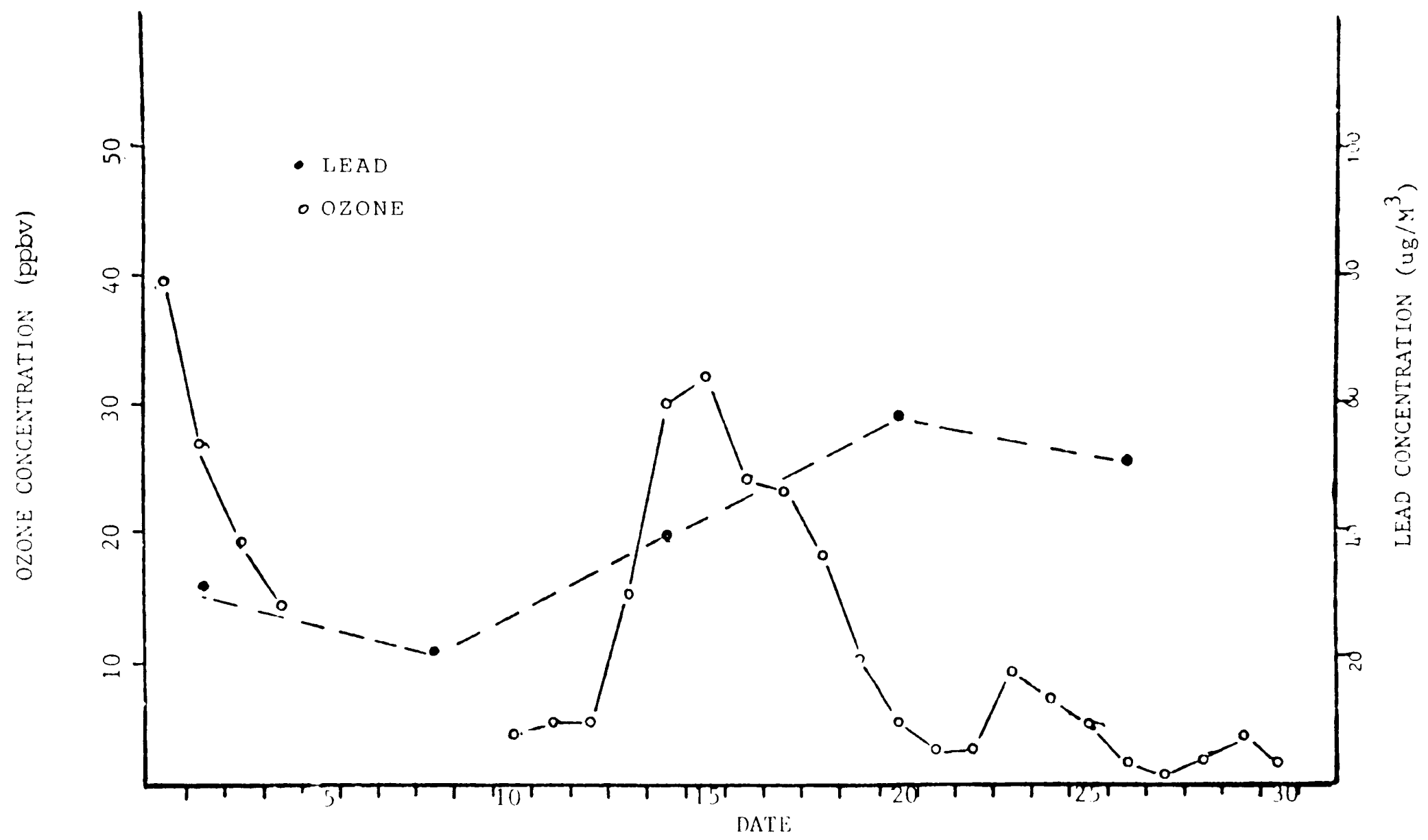

FIOURE 24: DAILY (ZZONE ANI) LEAI) CONCENTRATIONS: DADE COUNTY, JUNE, 1980. 


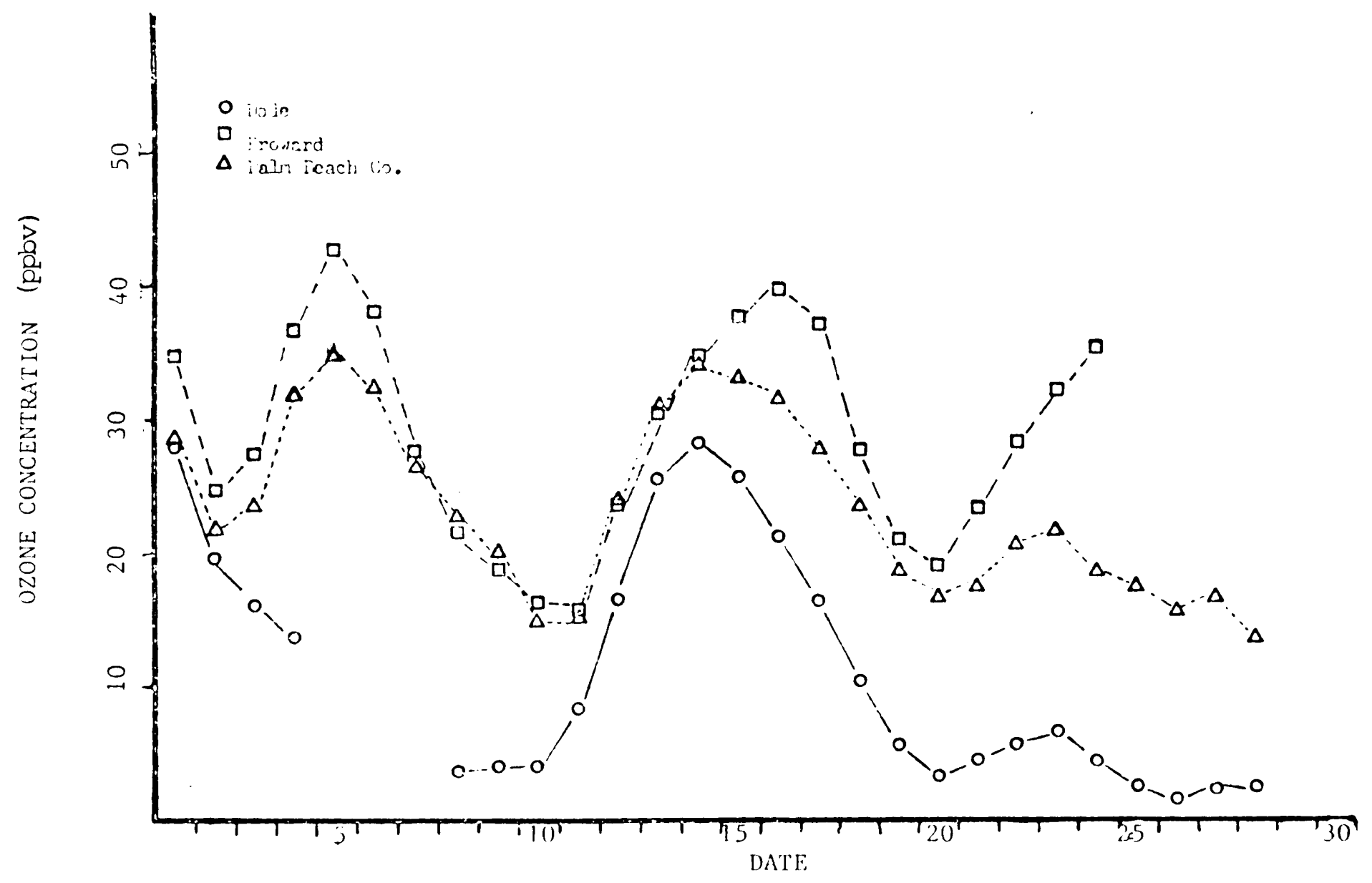

FICURE 25: OZOHE CONCINTRATIONS: SOUTHEAST FLORIDA, JUNE, 1980. 


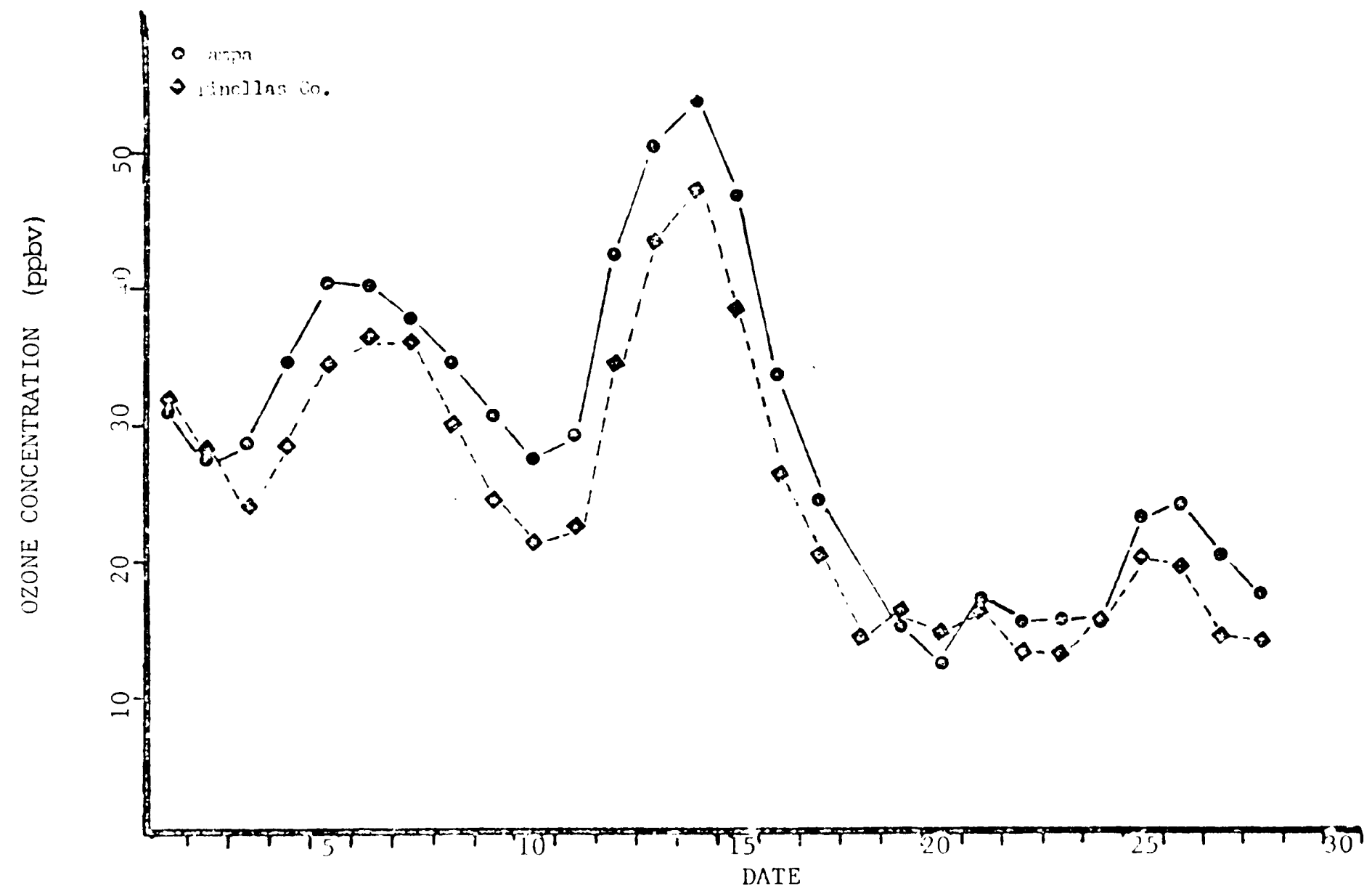

FIGURE 26: OZONE CONCENTRATJONS: TAMPA BAY AREA, JUNE, 1980. 
different as seen in Figure 27. The maximum values are much higher than in either Tampa or South Florida and continue at elevated levels until June 15. This portion of the graph bears little or no resemblance to the two previous graphs. Thus it appears different air masses were impacting on Northern and Southern Florida. Figure 28 agrees with this analysis. Once again South Florida was experiencing air coming from the Caribbean while North Florida experienced air coming across the Southeastern United States.

E. October 5-7, 1978. During October 5-7, 1978 Dade County experienced very high concentrations of ozone which exceeded the National Ambient Air Quality Standard. A comparison of the ozone and lead concentrations in Dade County, Figure 16, show both were elevated for this period. This indicated the ozone was generated locally. The Tampa Bay area, Figure 19, and Upper Florida, Figure 19, also had elevated concentrations of ozone, though not nearly as high as in Dade County. The data for Georgia, Figure 20, sustains this trend. This episode is thus very different from those presented previously.

Isentropic trajectories, Figure 29, shows that while the same type of transport was operative in the northern portion of the state, Miami was experiencing local stagnation. In this episode the classical picture of ozone generation and build-up under an inversion during a stagnate weather pattern was correct. However, the transport patterns 


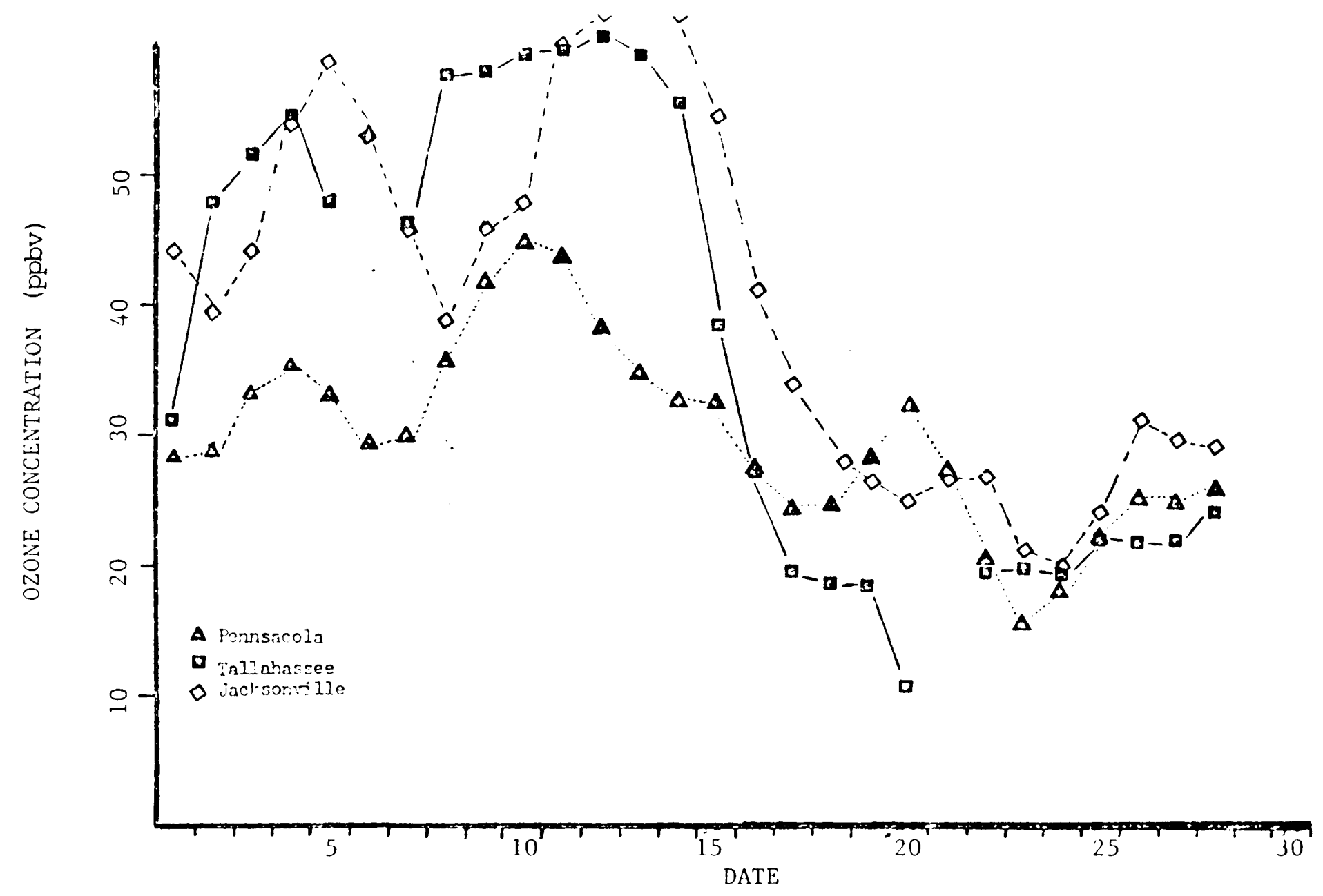

FIGURE 27: OZONE CONCENTRATIONS: UPPER FLORLDA, JLINE, 1980. 


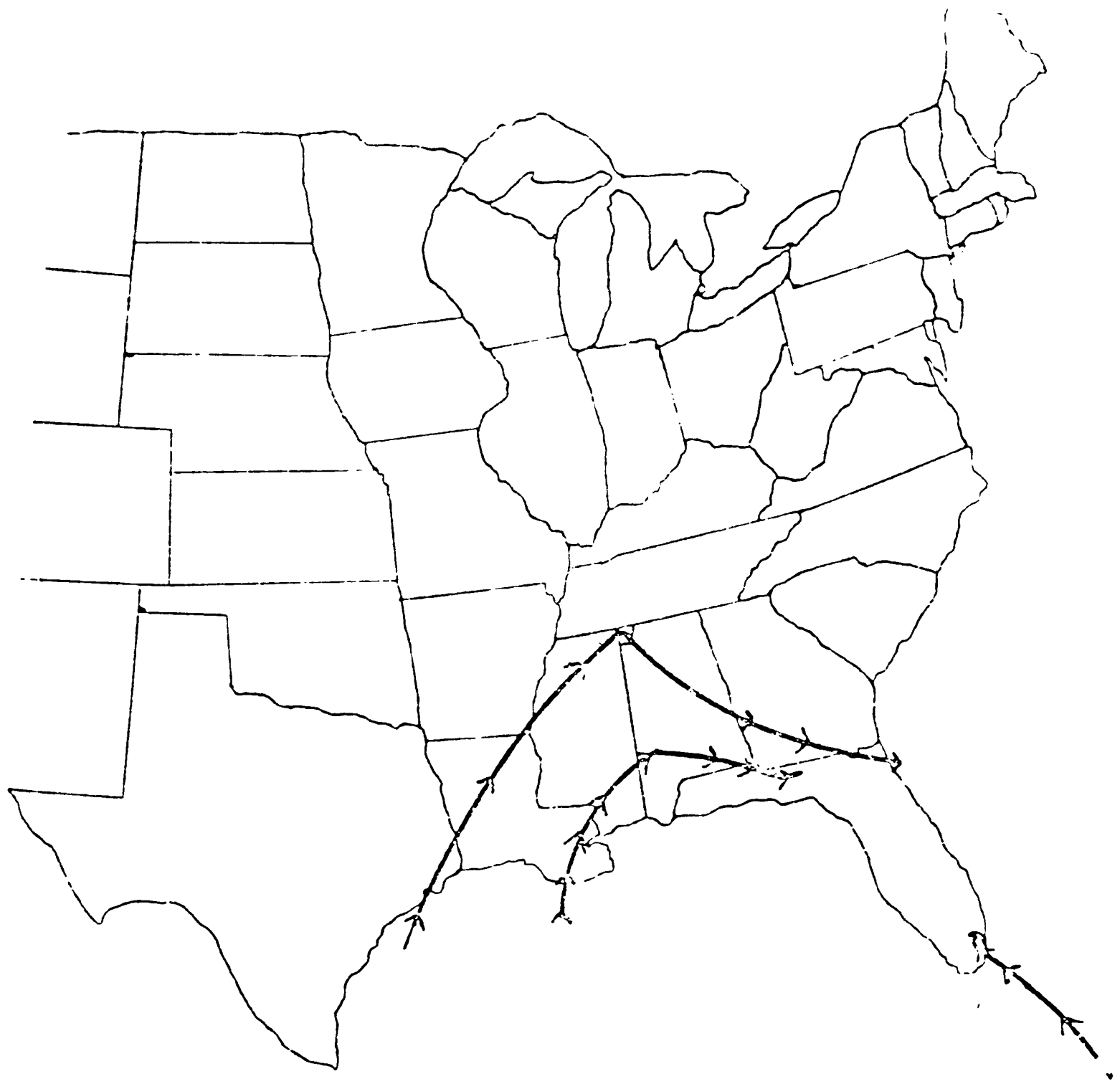

FIG!RE 28: ISENTROF IC TRAJECTORIES: JUNE 7-10, 1980 EPISODE. 


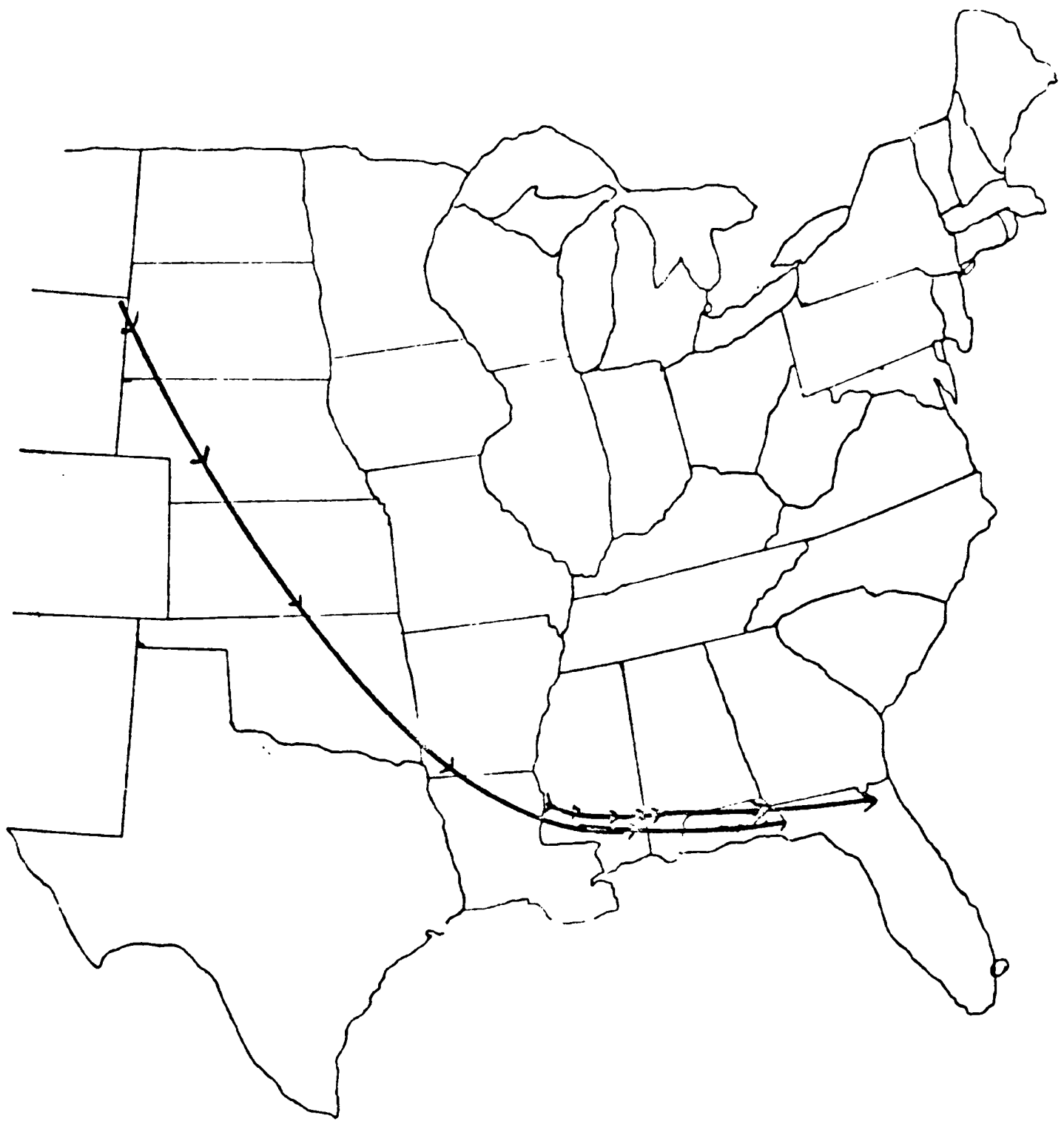

FIGURE 29: ISENTROPIC TRAJECTORIES: OCTOBER 5-7, 1978 EPISODE. 
for the upper portions of the state were similar to those indicated previously.

F. JULY 13-16, 1980. In this final episode South Florida experienced relatively low ozone concentrations while the remainder of the state reported violations of the standard. Figure 30 shows the ozone and lead concentrations in Dade County for this time period. The lead concentration appeared to decrease from July 14 to July 20, although actual data are not available on the other days. The three day running average for South Florida, Figure 31 , shows the ozone concentration reaching a maximum on July 15 . The Tampa Bay data shown in Figure 32 are very similar, The readings in Tampa were higher and reached their maximum on July 14. The Upper Florida data, Figure 33, continues this trend toward higher values with higher latitudes. The concentration reaches a maximum on July 13, which is slightly earlier than in the Tampa area.

This episode when considered along with the episodes presented previously confirms Altshuller's findings that the transport of ozone laden air across the Southeastern United States is a frequent occurrence. In this episode it is evident that the ozone concentration within the air mass decreases as it moves south. Also the maxima generally occur later indicating that the bulk of the ozone is associated with the air mass and is not generated locally. The shapes of the various curves are similar and the maxima 


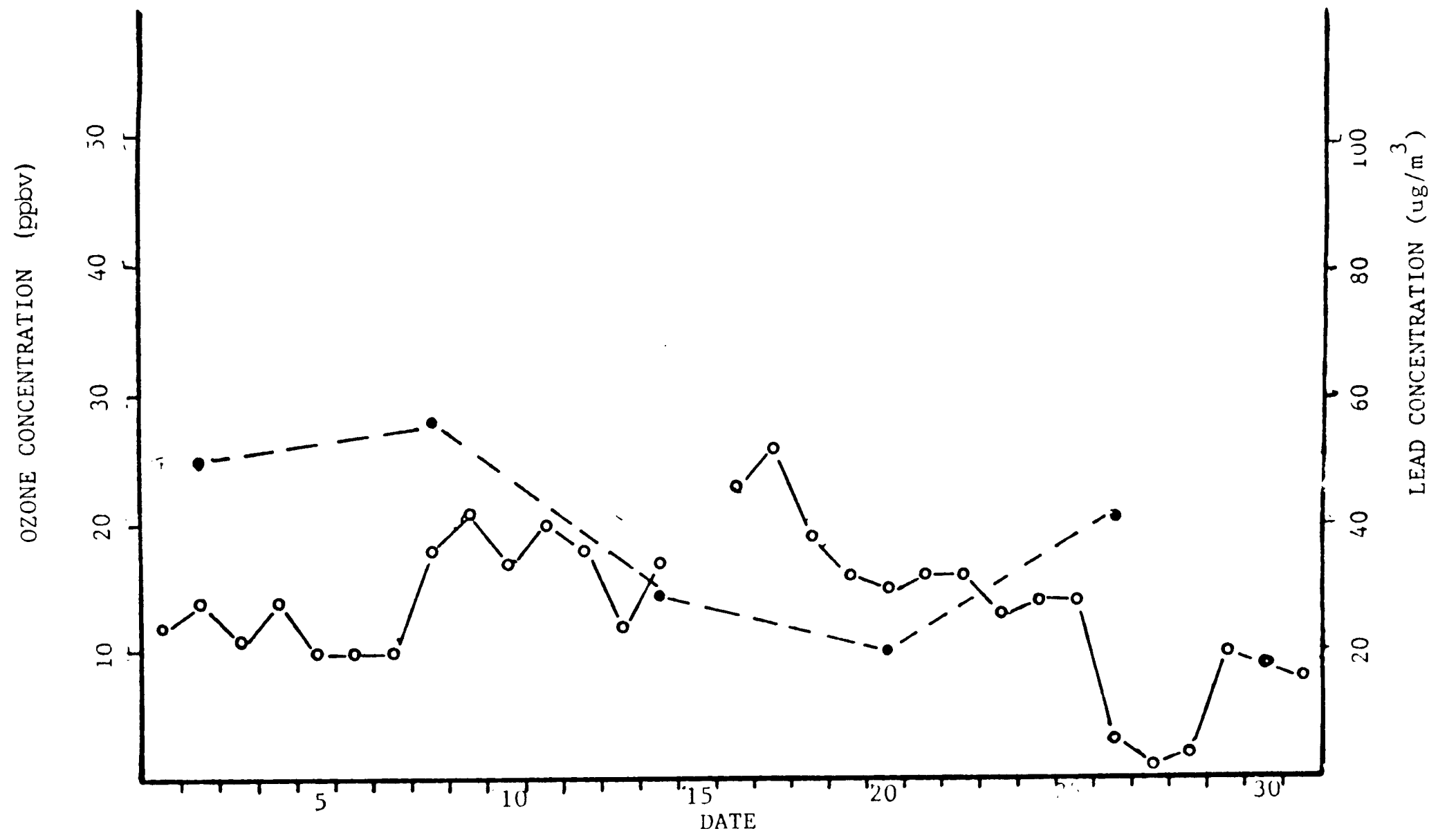

FIGURE 30: DAILY OZONE AND LEAD CONCENTRATIONS: DADE COUNTY, JULY, 1980. 


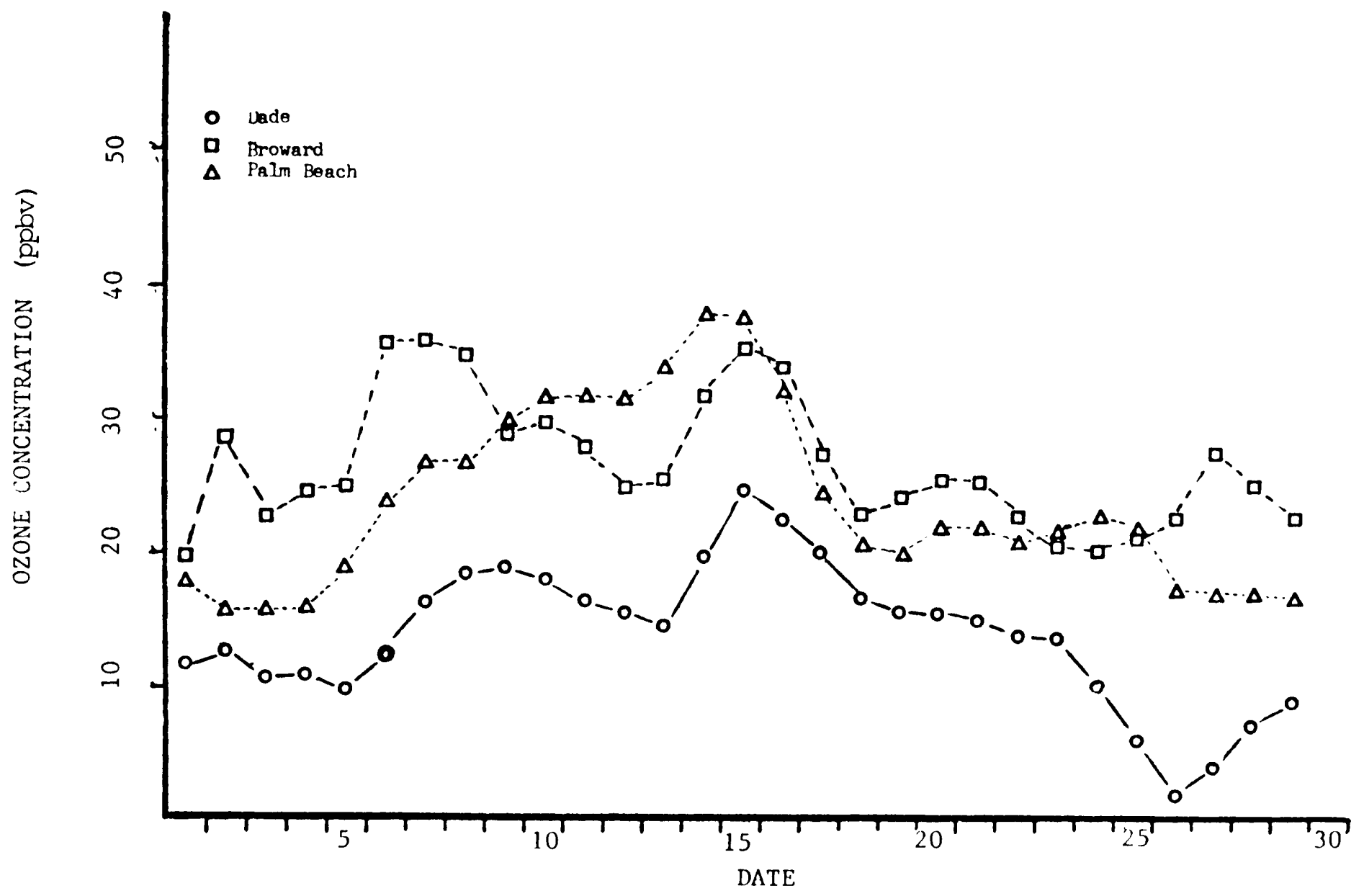

FIGURE 31: OZONE CONCENTRATIONS: SOUTHEAST FLORIDA, JULY, 1980. 


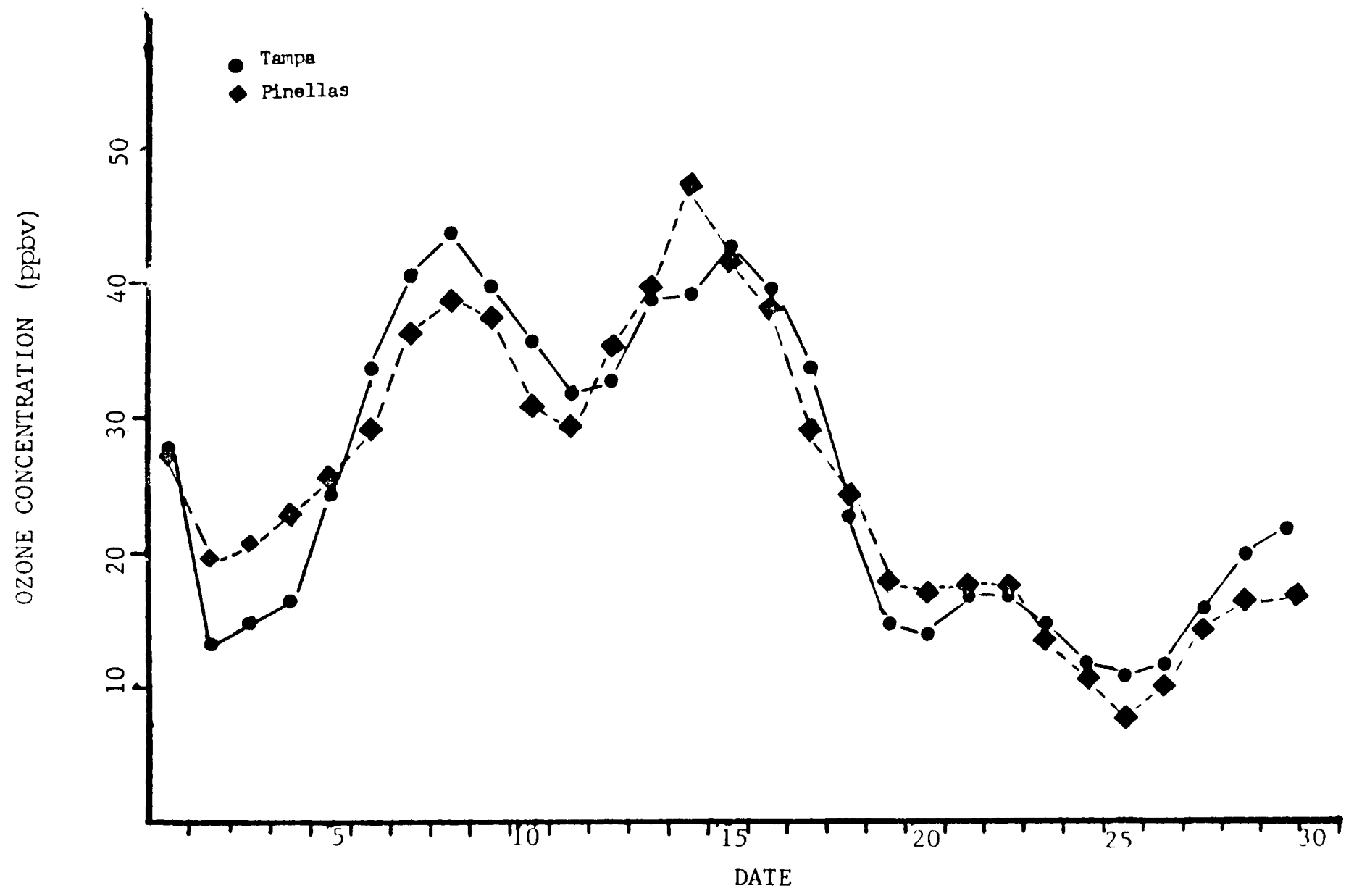

FIGURE 32: OZONE CONCENTRATIONS: TAMPA BAY AREA, JULY, 1980. 


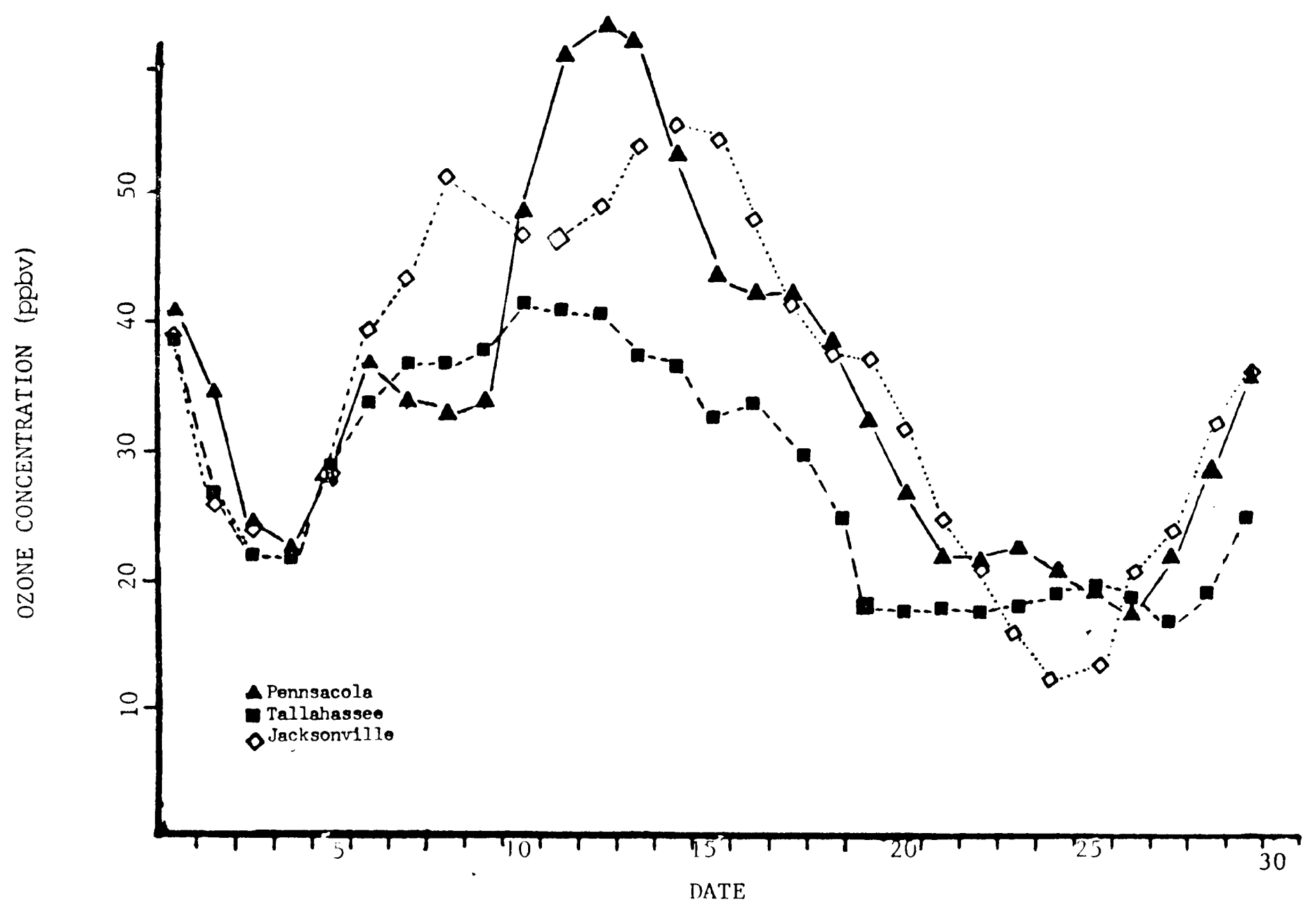

FIGURF 33: OZONE CONCENTRATIONS: UPPER FIORIDA, IULY, 1980. 
become better defined as the air mass moves southward. This is consistant with an air mass departing a varying source and developing in organization as a function of time.

In this episode the maximum values decrease approximately $10 \mathrm{ppb}$ per day as the air mass moves southward. This same trend on a much smaller spatial scale is seen in the South Florida data shown in Figure 31. Palm Beach has the highest ozone readings followed by Broward County and then Dade County

Given the curves for the various locations along with the trajectory analysis, it is possible to place some approximate limits on the residence time of ozone in this air mass. The residence time for a chemical species is defined as the time necessary for the concentration of the species to decrease to $1 /$ ef its original concentration. The residence time for a chemical species in the atmosphere is a function of both removal rates by dry or wet scavenging and the removal rate by chemical transformation or radioactive decay to other species. In this case ozone would most probably react to form oxygen. If one assumes that the average of the low readings at a given location is a measure of the locally generated background ozone, then the amount which is transported with the air mass can be calculated using the peak concentration values minus the background concentrations. When this is done the resulting concentrations can be related to a time scale through the trajectory analysis. This results in a half life of 11 hours and a 
residence time of 16 hours. These figures decrease if the annual geometric mean for each location is used instead of the minimum. The half-life then becomes 7.5 hours and the residence time is 11 hours. There is no way to estimate whether this value is a maximum or minimum residence time value. If all of the ozone in the air mass were generated at its origin with no precursers remaining and no ozone generated along the path, then the residence time calculated would be much longer than the value given. If all the ozone is local in origin, the calculation yields no information on the residence time. Estimations made by Anderson (1979) range from 80 hours for the half-life of ozone above the nocturnal inversion layer to 4 hours for ozone below an urban inversion layer. He also reports a rural half-1ife of ozone below the inversion layer of 9 hours. These correspond to residence times of 5.8 hours to 4.8 days. Thus the residence time calculated above appears to correspond to that for ozone which has been transported over long distances above the inversion layer. 
IV. CONCLUISIONS

Ozone values in South Florida were observed to increase above the National Ambient Air Quality Standard of 120 ppbv. Several different theories could explain these elevated levels. In the classical theory of ozone production, precursors emitted from predominately mobile sources react in the presence of sunlight to form ozone. It was thought that in South Florida the sea breeze effect would contribute to this production. In this scenario the precursors would be transported out over the ocean by the morning off shore breeze, ozone would begin to form and the air mass would be transported back on shore in the afternoon. The observed data do not support this theory in all the cases presented. The local lead production was low during most of the episodes, indicating a low production of precursors. Also, the similarity of ozone concentration trends in South Florida to other ares in Florida and the Southeastern United States indicates the source of ozone is not totally local in nature, although there is a local contribution.

Another possibility is the injection of stratospheric ozone into the troposphere. While this possibility was not completely ruled out, such intrusions appear to be rare at thease latitudes, especially in late summer, and the isentropic trajectories indicated a possible intrusion in only one case. This intrusion occured over the Great Lakes and would be expected to have little efect on South Florida. 
The last possibility considered, the long range transport of ozone within the lower troposphere, appears most $1 \mathrm{ikely}$

A summary of the six episodes analyzed in this thesis is given in Table 2. In only one of these episodes was Miami clearly responsible for the high ozone levels found locally. In all of the other cases ozone appears to have been generated farther north and then transported into Florida. In one case Miami clearly eluded high ozone levels due to the fact that the prevailing air mass over Miami came from the Caribbean while the more normal transport pattern existed over the remainder of the state. All of these episodes show a common pattern of transport over the Southeastern United States into Florida. In all of these cases the upper and middle portions of the state experienced elevated ozone concentrations due to this transport pattern. The level to which ozone concentrations rise in the various parts of the state appears to be largly a function of how well this transport pattern becomes established and hence the strength of the system.

While only six episodes have been presented, the occurrence of the stagnant high weather pattern, which is well documented, suggests this transport pattern is quite common. Thus local generation of ozone, which certainly occurs, cannot be invoked to account for every violation of the ozone standards as put forth by the Environmental protection Agency and the state of Florida. 
The consequences of this transport pattern is even more far reaching. If ozone is transported southward from the more northern states, then other chemical species must also be transported in a similar manner. Thus much of the "acid rain" occurring in south Florida may have a similar transport pattern. This suggests an inevitable spread of the effects of acid rain into south Florida. 
Table 2 .

Summary of Ozone Episodes

Episode

October

$16-18,1978$

August

$7-10,1980$

June

$1-10,1980$

October

$5-7,1978$

July

$13-16,1980$
Concentration

Levels of

Lead Ozone

J.Jow High

Low High

Low

Miami

Low

Low

High High

Low

High

Miami

Low

time air. Upper Florida

had high ozone values.

Miami experienced a stagnation. Upper Florida was similar to above.

Distinct pattern of lower ozone values with lower latidude. 


\section{REFERENCES}

Adams D. F. 1956. The effects of air pollution on plant life. A review. Am. Med. Assoc. Arch. of Ind. Health, 14, 199-245.

Altshuller A. P. 1978. Association of oxidant episodes with warm stagnating anticyclones. Air Pollut. Control Assoc. J. 28, 152-156.

Anderson L. G. 1979. Effects of nighttime chemistry upon the transport of ozone and ozone precursors. Air Pollut. Control Assoc. J. 29, 970-973.

Benedict H. M., Miller C. J. and Olson R. G. 1971. Impact of air pollution on plants in the United States, US EPA Bul1. No. APTD-0953, Research Triangle Park, North Carolina.

Bhatngar R. S. 1977. The Role of Superoxide in oxidant Induced Pulmonary Fibrosis, in "Biochemical Effects of Environmental Pollutants", Lee, S.D., Ed. pp. 47-58, Ann Arbor Science Publications, Inc. Ann Arbor, Michigan.

Buell G. C., Tokiwa, and Mueller P. K. 1965. Potential crosslinking agents in lung tissue. Formation and isolation after in-vivo exposure to ozone. Arch. Eviron. Health, $10,213$.

Danielson E. F. 1968.. Stratospheric-tropospheric exchange based on radioactivity, ozone and potential vorticity. J. Atmos. Sci. 25, 502-518.

Easton R. G. and Murphy S. D. 1967. Experimental ozone preexposure and histamine effect on the acute toxicity and respiratory function effections of histamine in guinea pigs. Arch. Environ. Health, $15,160$.

Environmental protection Agency 1974. Monitoring and air quality trends report. US EPA Bull. No. 450/1-74-007, Research Triangle Park, North Carolina.

Environmental Protection Agency 1975. Investigation of rural oxidant levels as related to urban hydrocarbon control strategies. US EPA Bull. No. 450/3-75-036, Research Triangle Park, North Carolina.

Environmental Protection Agency 1978. Air quality criteria for ozone and other photochemical oxidants. US EPA Bull. No. 600/8-78-004, Research Triangle Park, North Carolina. 
Environmental Protection Agency 1979a. National primary and secondary ambient air quality standards. Code of the Federal Register, 40 CFR 50, Federal Register, 44 , no. 28, Feb. 8, 1979 .

Environmental Protection Agengy 1979b. Ambient air quality surveillance. Code of the Federal Register, 40 CFR 58, May $10,1979$.

Haagen-Smit A. J. 1952. Chemistry and physiology of Los Angeles smog. Ind. Eng. Chem. 44, 1342-1346.

Haagenson P. L. and Shapiro M. A. 1979. Isentropic trajectories for derivation of objectively ananlzed meteorological parameters. Technical Note TN-149-STR, National Center for Atmospheric Research, Boulder, CO.

Haagenson P. L., Shapiro M. A. and Middleton P. 1981. A case study relating high ground level ozone to enhanced photochemically and isentopic transport form the stratosphere. J. Geophys. Res.,86, 5231-5237.

Hathaway J. A. and Terril R. E. 1962. Metabolic effects of chronic ozone exposure on rats. Am. Hygiene Assoc. J. 24, 229-232.

Husian I., Coffey P. E., Meyers R. E. and Cederwall R. J. 1977. Ozone transport from stratosphere to troposphere. Geophysical Res. Lett. 4 , 363-365.

Ishida R. and Takehashi T. 1975. Increased DNA chain breakage by combined action of bleonycin and superoxide radical. Biochem. Biophys. Res. Comm. 66, 1432 .

Junge C.E. 1963. "Air Chemistry and Radioactivity." pp. 44-55, Academic Press, New York.

Mansfield T. A. 1973. The role of stomata in determining the responses of plants to air pollutants. Comm. Plant Sci. $2,11-20$.

Motley H. L., Smart R. H. and Leftwich C. I. 1959. Effect of polluted Los Aggeles air (SMOG) on lung volume measurements. J. Am. Med. Assoc. 171, 1469-1477.

Moore H. E., Poet $2 S_{2}$. . and Martell, E. A. 1977. Vertical profiles of ${ }^{22} \mathrm{Rn}$ and its long-lived daughters over the Eastern Pacific. Environ. Sci. Tech. 11, 1207-1210.

Mudd J. B. and Freeman B. A. 1977. Reaction of ozone with biological membranes, in "Biological Effects of Enviornmental Pollutants." Lee, S. D., Ed. pp. 97-133, Ann Arbor Science Publishers, Inc., Ann Arbor, Michigan. 
Mustafa M. G., Hacker A. D., Ospitall J. J. Hussain M. Z. and Lee S. D. 1977. Riochemical effects of environmental oxidant pollutants in animals' lungs, in "Biochemical Effects of Fnvironmental pollutants." Lee, S. D., Ed. pp. 97-134, Ann Arbor Science Publishers, Inc., Ann Arbor, Michigan.

Poet S. E., Moore H. E. and Martell E. A. 1972. Lead-210, bismuth-210 and polomium-210 in the atmosphere:

Accurate ratio measurement and application to aerosol residence time determination. J. Geophys. Res. 77 , $6515-6527$.

Reiter R., Sladkovic R., Potzl K., Carnuth W. and Kanter H. J. 1977. Studies on the influx of stratospheric air into the lower troposphere using cosmic ray produced radionuclides and fallout. Arch. Met. Geophys. Biokl. Ser A 20, 211 .

Remmers J. E. and Balchum O. J. 1965. Effects of Los Angeles urban air upon respiratory function of emphysematous patients. Presented at 58th annual meeting of the Air Pollution Control Association, Toronto, Canada, June, 1965 .

Salop J. and Maier G. F. 1978. A study of ozone levels in a maritime and land environment. Air pollution Contr. Assoc. J. 28, 1212-1220.

Schoettlin C. E. and Landau E. 1961. Air pollution and astmatic attacks in the Los Angeles area. Public Health Report $76,545-548$.

Stern A. C. 1977. "Air Pollution Volume II: The Effects of Air Pollution." pp. 233-264, Academic Press, New York, New York.

Texas Air Control Board 1974. Ambient air quality surveyKountze, Beaumont, Port Arthur and McFaddin Beach, Texas. Texas Air Control Board, April, 1974.

Tingey D. T. 1977. Ozone induced alterations in plant growth and metabolism. Proceedings of the International Conference on Photochemical Oxidant Pollution and Its Control, Vol. II. pp. 601-609 Bull. No. EPA-G00/3-77$001 b$, Environmental Protection Agency, Research Triangle Park, NC.

Walbott G. L. 1973. "Health Effects of Environmental pollutants." pp. 88-91, C. V. Mosby Co, St. Louis, Missouri. 
Williamson S. J. 1973. "Fundamentals of Air Pollution." pp. 137-138, Addison-Wesley Pub. Co., Reading, Mass.

Wolff G. T., Lioy P. J., Meyers R. E., Cederwall G. D., Paseri R. F. and Taylor R. S. 1977. Anatomy of two ozone transport episodes in the Washington D. C. to Boston, Mass. corridor. Environ. Sci. Tech. 11, 506510 .

Van Rossem A. and Talem H. W. 1931. The appearance of

atmopheric cracks in streched rubber. Kautschuk 7:79$\underline{86}, 115-117$. 